\title{
Fossil calibration of Magnoliidae, an ancient lineage of angiosperms
}

\author{
Julien Massoni, James Doyle, and Hervé Sauquet
}

\begin{abstract}
In order to investigate the diversification of angiosperms, an accurate temporal framework is needed. Molecular dating methods thoroughly calibrated with the fossil record can provide estimates of this evolutionary time scale. Because of their position in the phylogenetic tree of angiosperms, Magnoliidae (10,000 species) are of primary importance for the investigation of the evolutionary history of flowering plants. The rich fossil record of the group, beginning in the Cretaceous, has a global distribution. Among the hundred extinct species of Magnoliidae described, several have been included in phylogenetic analyses alongside extant species, providing reliable calibration points for molecular dating studies. Until now, few fossils have been used as calibration points of Magnoliidae, and detailed justifications of their phylogenetic position and absolute age have been lacking. Here, we review the position and ages for 10 fossils of Magnoliidae, selected because of their previous inclusion in phylogenetic analyses of extant and fossil taxa. This study allows us to propose an updated calibration scheme for dating the evolutionary history of Magnoliidae.
\end{abstract}

Julien Massoni. Laboratoire Ecologie, Systématique, Evolution, Université Paris-Sud, CNRS UMR 8079, 91405 Orsay, France. massoni.julien@gmail.com

James Doyle. Department of Evolution and Ecology, University of California, Davis, CA 95616, USA. jadoyle@ucdavis.edu

Hervé Sauquet. Laboratoire Ecologie, Systématique, Evolution, Université Paris-Sud, CNRS UMR 8079, 91405 Orsay, France. herve.sauquet@u-psud.fr

Keywords: fossil calibration; Canellales; Laurales; Magnoliales; Magnoliidae; Piperales

PE Article Number: 18.1.2FC

Copyright: Palaeontological Association February 2015

Submission: 10 October 2013. Acceptance: 1 July 2014

Massoni, Julien, Doyle, James, and Sauquet, Hervé. 2015. Fossil calibration of Magnoliidae, an ancient lineage of angiosperms. Palaeontologia Electronica 18.1.2FC; 1-25;

palaeo-electronica.org/content/fc-2

Calibrations published in the Fossil Calibration Series are accessioned into the Fossil Calibration Database (www.fossilcalibrations.org). The Database is a dynamic tool for finding up-to-date calibrations, and calibration data will be updated and annotated as interpretations change. In contrast, the Fossil Calibration papers are a permanent published record of the information on which the calibrations were originally based. Please refer to the Database for the latest data. 


\section{INTRODUCTION}

Among the first diverging lineages of angiosperms (outside monocots and eudicots), Magnoliidae are the largest clade, comprising about 10,000 species divided among 20 families and four orders: Magnoliales, Laurales, Canellales, and Piperales (APG III, 2009). Although Magnoliidae have a global distribution extending into the temperate zones of both hemispheres, most of their diversity occurs in tropical areas. This group has been supported as monophyletic by the great majority of molecular phylogenetic studies (Qiu et al., 1999, 2000, 2005, 2006, 2010; Soltis et al., 1999, 2000a, 2000b, 2007, 2011; Mathews and Donoghue, 1999, 2000; Savolainen et al., 2000; Graham and Olmstead, 2000; Zanis et al., 2002, 2003; Nickrent et al., 2002; Borsch et al., 2003; Hilu et al., 2003; Jansen et al., 2007; Moore et al., 2007, 2010; Burleigh et al., 2009). Although the majority of the relationships among families of Magnoliidae are well established, the exact positions of Hydnoraceae and Magnoliaceae and the relationships among Hernandiaceae, Lauraceae, and Monimiaceae are still debated (Figure 1; Massoni et al., 2014). This group has a rich fossil record starting in the Early Cretaceous. Cretaceous fossils assigned to Magnoliidae have been found in many parts of the world: South America (e.g., Mohr and Bernardesde-Oliveira, 2004; Mohr et al., 2013), North America (e.g., Dilcher and Crane, 1984; Crepet et al., 2005), Europe (e.g., Friis et al., 2010, 2011), Asia (e.g., Takahashi et al., 2001, 2008), Africa (e.g., Doyle et al., 1990), Australasia (e.g., Dettmann et al., 2009), and Antarctica (e.g., Poole and Gottwald, 2001; Eklund, 2003). Fossil Magnoliidae come in a variety of forms, from wood (e.g., Herendeen, 1991; Poole and Gottwald, 2001; Schöning and Bandel, 2004) and leaves (e.g., Upchurch and Dilcher, 1990; Kvaček, 1992) to flowers (e.g., Dilcher and Crane, 1984; Drinnan et al., 1990; Takahashi et al., 2008; Friis et al., 2011), fruits (e.g., Friis et al., 2010, 2011), seeds (e.g., Knobloch and Mai, 1986; Frumin and Friis, 1996), and pollen (e.g., Doyle et al., 1990; Macphail et al., 1994). Because the number of characters observed in such fossils is often limited, establishing their phylogenetic relationships to extant taxa is not always straightforward. However, among fossils assigned to Magnoliidae, several are characterized by good to exceptional preservation and a large number of systematically useful characters, such as the lignitized and charcoalified flowers considered here.
Investigating the evolutionary history of organisms often requires a temporal context, which until recently was based almost exclusively on the fossil record. Insofar as fossils can be placed in a phylogenetic tree, a paleontological approach can provide minimum ages and, to a lesser extent, maximum ages for clades. Over the past two decades, this method has been supplemented with molecular dating approaches, which generate estimates of absolute divergence times throughout the tree (i.e., not just in the neighborhood of a particular fossil). The first such studies were based on the concept of a molecular clock, but the development of new methods has helped to relax the assumption of a strict clock across the tree.

In molecular dating analyses, the fossil record provides minimum bounds to calibrate the trees. These calibration points are not only used to convert the time scale of relative ages into one of absolute ages, but they also serve as anchors for modeling molecular rate variation across the tree (e.g., Sanderson, 1997; Sauquet et al., 2012). In this context, calibration is being recognized as a critical point and can have a drastic influence on results (Inoue et al., 2010; Meredith et al., 2011; Sauquet et al., 2012). Because of re-evaluation of the boundaries of geological time units, and sometimes re-dating of fossil beds, the accepted age of a fossil can change through time (Gandolfo et al., 2008). Therefore, an exhaustive geological review is essential in order to provide an accurate minimum age (Parham et al., 2012). Except for recently developed total evidence dating approaches that combine the phylogenetic analysis of extant and fossil taxa with the estimation of divergence times (Pyron 2011; Ronquist et al., 2012), a review of the phylogenetic position of a fossil is a second crucial point in the calibration process (Gandolfo et al., 2008; Parham et al., 2012; Sauquet et al., 2012). Molecular scaffold approaches (analyzing morphological data with the topology of living taxa fixed by a backbone constraint tree; Springer et al., 2001) or total evidence approaches (using both molecular and morphological data; Kluge, 1989) can provide a genuine test for the phylogenetic position of extinct taxa. A decision regarding the identity of the node calibrated by a fossil has to take into account the uncertainty of its phylogenetic position and the uncertainty of the relationships among extant species. A number of fossil taxa of Magnoliidae have already been included in morphological data matrices and analyzed with a phylogenetic approach taking into account both morphological and molecular data (e.g., Doyle and Endress, 2010; von 
TABLE 1. Summary of the calibration points provided in the present paper. Abbreviations: Ma, million anni.

\begin{tabular}{|c|c|c|}
\hline Fossil Taxon & Node & Minimum Age \\
\hline Endressinia brasiliana & Crown-group Magnoliineae (Doyle and Endress, 2010; Mohr et al., 2013) & $112.6 \mathrm{Ma}$ \\
\hline Schenkeriphyllum glanduliferum & Crown-group Magnoliineae (Mohr et al., 2013) & $112.6 \mathrm{Ma}$ \\
\hline Archaeanthus linnenbergeri & Stem Magnoliaceae (Doyle and Endress, 2010) & $96.5 \mathrm{Ma}$ \\
\hline Virginianthus calycanthoides & Crown-group Laurales (Doyle et al., 2008) & $107.7 \mathrm{Ma}$ \\
\hline Lovellea wintonensis & Crown-group Laurales (Dettmann et al., 2009) & $100.1 \mathrm{Ma}$ \\
\hline Jerseyanthus calycanthoides & Crown-group Calycanthoideae (Crepet et al., 2005) & $85.8 \mathrm{Ma}$ \\
\hline Cohongarootonia hispida & Crown-group core Laurales (von Balthazar et al., 2011) & $107.7 \mathrm{Ma}$ \\
\hline Mauldinia mirabilis & Crown-group core Laurales (Doyle and Endress, 2010) & $95.5 \mathrm{Ma}$ \\
\hline Walkeripollis gabonensis & Crown-group Canellales (Doyle and Endress, 2010) & $125.9 \mathrm{Ma}$ \\
\hline Saururus tuckerae & Stem node of extant Saururus (Smith and Stockey, 2007) & $44.3 \mathrm{Ma}$ \\
\hline
\end{tabular}

Balthazar et al., 2011). These previous studies should, in principle, allow firm calibration of a molecular time scale, which is currently lacking for Magnoliidae (Forest and Chase, 2009).

The purpose of the present study is to provide a reliable calibration scheme for the Magnoliidae, usable as a starting point for any molecular dating study of Magnoliidae or subgroups of this clade, as well as higher-level angiosperm divergence time studies. To do so, we have reviewed the geologic age and phylogenetic relationships of all fossils of Magnoliidae that have been included in at least one phylogenetic analysis (10 fossils, Table 1$)$. For this paper, we did not re-examine the fossil specimens. Instead, our argumentation is based on previously published descriptive and phylogenetic studies. Nine of these are represented by fossil flowers, in four cases with associated vegetative parts, but one (Walkeripollis gabonensis) is based on dispersed pollen grains that have a particularly diagnostic combination of characters. Following a strict minimum age philosophy, we propose to calibrate the most recent common ancestor of all most parsimonious assignments of previous analyses, and we provide associated synapomorphies when they were mentioned in the original study.

Most of the fossils treated here are from continental deposits that contain neither marine fossils that would allow direct correlation with the marinebased relative time scale, nor minerals suitable for absolute radiometric dating. In most cases, their ages are based on indirect palynological correlations with pollen and spore sequences that are dated by marine fossils. For example, for the US Atlantic Coastal Plain, these reference sections are in the US Western Interior and Gulf Coast (Hedlund and Norris, 1968; Ward, 1986; Ludvigson et al., 2010) and western Europe (Góczán et al., 1967; Kemp, 1970; Laing, 1975; Hughes, 1994;
Heimhofer et al., 2005, 2007; Hochuli et al., 2006), which belonged to the same Southern Laurasian phytogeographic province of Brenner (1976; see Doyle, 1969a, 1977, 1992; Wolfe and Pakiser, 1971; Doyle and Hickey, 1976; Doyle and Robbins, 1977; Christopher, 1979; Christopher et al., 1999; Christopher and Prowell, 2010). Some of these fossils, or others from the same localities, have been used for calibration in previous molecular dating studies (Doyle et al., 2004; Magallón and Castillo, 2009; Clarke et al., 2011; Pirie and Doyle, 2012). In some cases, Clarke et al. (2011) proposed much younger minimum ages than those recommended here because of conflicting conclusions of earlier authors on the phylogenetic position of fossils or on stratigraphic correlations. We argue that these minimum ages can be improved with critical examination. Our treatment includes a review of the age of units in the Atlantic Coastal Plain, the source of four of the fossils treated here, and several non-magnoliid taxa used in other dating analyses, which has been a subject of recent discussion (Hochuli et al., 2006).

Absolute ages used here follow Ogg and Hinnov (2012). This chapter of the revised Geologic Time Scale of Gradstein (2012) is the most recent comprehensive synthesis of absolute dates for the Cretaceous, including estimated ages for each substage, which we derive here from the charts in figure 27.6 of Ogg and Hinnov (2012). When possible, use of substage boundaries is preferable to the use of stage boundaries only, which can be overly conservative when dealing with stages as long as the Albian (ca. $12.5 \mathrm{Ma}$ ). In their table 27.2, Ogg and Hinnov (2012) included the estimated uncertainty for the boundaries of stages (2-sigma), but not for the boundaries of substages. In order to be conservative and to take into account existing estimates of uncertainty, those of our recommended 
minimum ages that correspond to stage boundaries are the point estimates of Ogg and Hinnov (2012) minus the associated two standard deviations. Many radiometric dates are available for the Late Cretaceous, thanks particularly to the abundance of bentonites. There are fewer radiometric dates for the Early Cretaceous, but there has been much progress in integrating these with sequence stratigraphy, magnetostratigraphy, isotope stratigraphy, and cyclostratigraphy (which relates cyclic sedimentation to astronomical cycles of the earth's orbit and tilt). Significantly younger ages and shorter durations for several stages were proposed by Fiet et al. ( 2006) based on K/Ar glauconite dates and cyclostratigraphy. Scott et al. (2009) suggested that these ages may be too young due to argon leakage, a problem in glauconites, and Fiet et al. (2006) recognized that they require testing with studies on bentonites. By contrast, Huang et al. (2010), also using cyclostratigraphy, obtained ages for the Aptian and Albian very close to those of Ogg and Hinnov (2012) and suggested that the shorter durations of Fiet et al. (2006) were due to incompleteness of the sections studied. The dates of Ogg and Hinnov (2012) still involve considerable extrapolation, but use of this single comprehensive scheme should make correction of the calibrations presented here easier if this becomes necessary in the future.

We organized the present text by sections on calibrated nodes. When several fossil species were available to calibrate the same node, we used the oldest (reported as the "preferred fossil" section in the text) to define the age associated with the calibration. The remaining extinct species that could be used to calibrate the same node are reported as "additional fossils." We organized the "additional fossil" sections following the same structure used for the "preferred fossil" section. We proceeded in this way because future phylogenetic and stratigraphic studies may refine or modify the position or the age of the fossils, leading to future improvement of the current scheme. This is especially relevant when the older fossils are less completely known than the younger ones. We also believe that reporting the complete details of redundant fossils identified as suitable calibrations is useful to increase confidence in the proposed calibration of the corresponding nodes.

\section{NODE 1: CROWN-GROUP MAGNOLIINEAE}

\section{Fossil Taxon 1 (preferred, given current knowledge)}

Endressinia brasiliana Mohr and Bernardes-deOliveira, 2004

Node Calibrated. Crown-group Magnoliineae (Doyle and Endress, 2010; Mohr et al., 2013)

Reference Specimen. MB. PB. 2001/1455 in Museum of Natural History, Institute of Paleontology, Berlin, Germany (holotype; branching axis with attached leaves and flowers).

Phylogenetic Justification. A molecular scaffold analysis by Doyle and Endress (2010), including 64 extant taxa sampled across angiosperms and 142 morphological characters, placed Endressinia in seven different most parsimonious positions: all positions within the crown group of the clade Himantandraceae + Degeneriaceae + Eupomatiaceae + Annonaceae (each represented as one terminal), or as the sister group of this clade. These relationships were supported by one unequivocal synapomorphy, the presence of glands on the stamens or staminodes (Doyle and Endress, 2010). A more recent molecular scaffold analysis (Mohr et al., 2013), which used a modified version of the morphological data set of Doyle and Endress (2010) reduced to Magnoliales, Laurales, and Canellales (as outgroup), placed Endressinia as the sister group of Schenkeriphyllum glanduliferum (another fossil from the same deposit, discussed below), with the clade of the two fossils being the sister group of Magnoliaceae. Endressinia and Schenkeriphyllum were united by sessile leaf blade (a new character) and linked with Magnoliaceae by sheathing leaf base and dry fruit wall. As noted by Mohr et al. (2013), Doyle and Endress (2010) did not score Endressinia as having a sheathing leaf base. This was probably because the sheath was formed from the unusual sessile leaf blade, rather than a leaf base separated from the blade by a petiole, but this difference does not rule out homology of the character. We have not attempted to resolve this conflict with a new analysis. The implications for dating are complicated by the fact that the position of Magnoliaceae within Magnoliales is still debated. Two alternative positions have been supported by most analyses: either as the sister group of a clade of Degeneriaceae + Himantandraceae (Soltis et al., 1999, 2007; Qiu et al., 2000, 2005, 2006; Savolainen et al., 2000; Zanis et al., 2002, 2003), or sister to a clade of Degeneriaceae + Himantandraceae + Eupomatiaceae + Annonaceae (Doyle and Endress, 2000; Sauquet et al., 


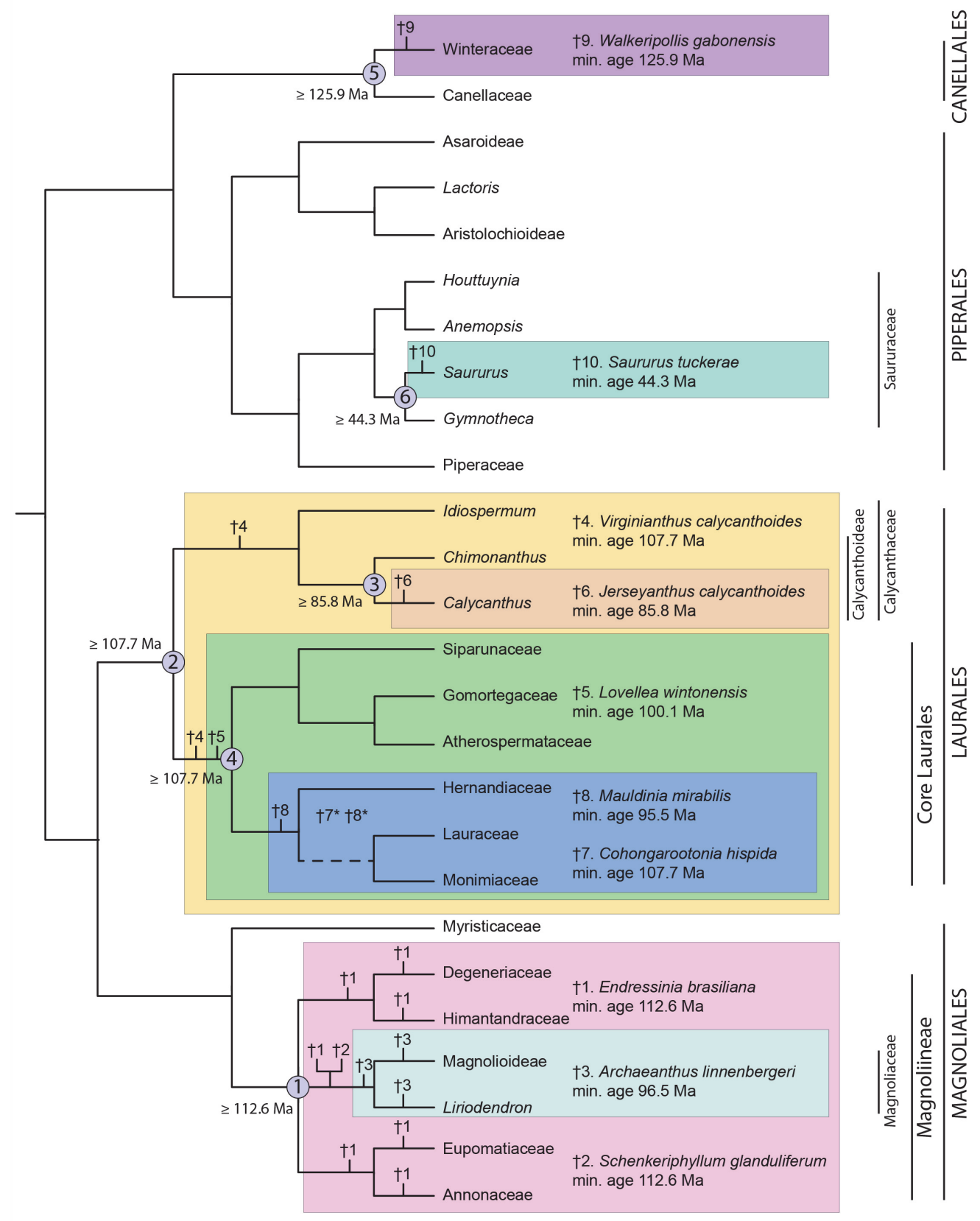

FIGURE 1. Simplified phylogenetic tree of Magnoliidae, after Massoni et al. (2014). Hydnoraceae (Piperales) are excluded, because the family was not included in original publications positioning the 10 fossils considered here. Colored boxes summarize the positions of fossils reviewed in the present paper. Their specific positions are figured by small branches with the number of the corresponding fossil at the tip. These correspond to the most parsimonious position(s) found for each fossil in previous phylogenetic analyses (see text for details). The minimum ages provided by the fossils are presented at the nodes they calibrate. The dashed branch refers to the phylogenetic uncertainty about relationships among Hernandiaceae, Lauraceae, and Monimiaceae (the position of Fossil 7 is on a branch not represented here, corresponding to a different set of relationships among these three families). Fossils are numbered following their order in the text. Abbreviations: Ma, million anni. 
2003). However, the results of both Doyle and Endress (2010) and Mohr et al. (2013) support a position of Endressinia within the crown group of Magnoliineae, the well-supported clade of five families that is sister to Myristicaceae (Sauquet et al., 2003), and each study alone leads to use of this fossil to calibrate the crown node of this clade. Therefore, Endressinia provides a safe minimum age for the crown node of Magnoliineae (Figure 1). Minimum Age. Aptian-Albian boundary, 112.6 Ma $(113 \pm 0.4 \mathrm{Ma})$

Age Justification. The fossil considered here was collected from the Crato Formation in the Araripe sedimentary basin of northeastern Brazil (Mohr et al., 2013). Mohr and Bernardes-de-Oliveira (2004) assumed that the Crato Formation is late Aptian or early Albian in age, based on numerous previous estimates (e.g., Pons et al., 1996). Because of this uncertainty, Clarke et al. (2011) proposed a minimum age for the Crato of $98.7 \mathrm{Ma}$, the top of the Albian. However, evidence has been accumulating in favor of a late Aptian age (Coimbra et al., 2002). Most recently, using gymnosperm pollen and dinoflagellates to correlate with better-dated sections, Heimhofer and Hochuli (2010) concluded that the Aptian-Albian boundary lies above the Crato Formation, and this was accepted by Mohr et al. (2013). We therefore propose a minimum age of 112.6 Ma for Endressinia, the Aptian-Albian boundary (113 $\pm 0.4 \mathrm{Ma}$; Ogg and Hinnov, 2012).

Previous Use as Calibration. Endressinia has been used in several molecular dating studies with different ages and as a calibration for different nodes than recommended in the present study. In order to estimate divergence times within angiosperms, Magallón and Castillo (2009) used Endressinia with a similar age (112 Ma) but applied this age to the stem lineage of Magnoliineae. The same age was used by Pirie and Doyle (2012) to fix the age of the stem node of the clade of Eupomatiaceae and Annonaceae, sister to Magnoliaceae in their study. Surveswaran et al. (2010) used the fossil to provide a minimum age for the same stem lineage corresponding, in their study, to the same node recommended here (crown node Magnoliineae). However, they used an age of $115 \mathrm{Ma}$. Finally, Couvreur et al. (2011) calibrated the same node (crown node Magnoliineae) with the same age but using it as a fixed age constraint.

\section{Fossil Taxon 2 (additional)}

Schenkeriphyllum glanduliferum Mohr, Coiffard, and Bernardes-de-Oliveira, 2013
Node Calibrated. Crown-group Magnoliineae (Mohr et al., 2013)

Reference Specimen. MB. Pb. 1999/2356 in Museum of Natural History, Institute of Paleontology, Berlin, Germany (holotype; branching axis with leaves and flowers).

Additional Specimens. MB Pb. 2008/350. Paratype (branching axis with leaves and flowers; will be deposited at the Geosciences Institute of the University of São Paulo, Brazil, and is being stored with the number GP/3T2442).

MB.Pb. 2002/1336 (specimen with poorly preserved flowers).

MB. Pb. 1997/1219 (twigs with attached leaves).

MB. Pb. 1999/575, 1999/577A plus 1999/577B (dispersed leaves).

Phylogenetic Justification. As discussed for Endressinia (Fossil 1), the molecular scaffold analysis of Mohr et al. (2013) placed Schenkeriphyllum glanduliferum in a single most parsimonious position, together with Endressinia brasiliana, as sister to the Magnoliaceae. This result implies that Schenkeriphyllum provides a minimum age for the stem node of Magnoliaceae or the crown node of Magnoliineae, which are the same in the reference backbone tree used by Mohr et al. (2013). Because the position of Magnoliaceae with respect to Himantandraceae + Degeneriaceae and Eupomatiaceae + Annonaceae remains unresolved, as discussed under Endressinia (Soltis et al., 1999, 2007; Doyle and Endress, 2000; Qiu et al., 2000, 2005, 2006; Savolainen et al., 2000; Zanis et al., 2002, 2003; Sauquet et al., 2003), and the position of Endressinia is debated (see phylogenetic justification for Endressinia; Doyle and Endress, 2010; Mohr et al., 2013), we propose to use the age of Schenkeriphyllum conservatively as a minimum age for crown group Magnoliineae (Figure 1).

Minimum Age. Aptian-Albian boundary, 112.6 Ma $(113 \pm 0.4 \mathrm{Ma})$

Age Justification. Schenkeriphyllum was collected from the same sedimentary unit as Endressinia, the Crato Formation in the Araripe basin of northeastern Brazil (Mohr et al., 2013). As discussed for Endressinia (Fossil 1), we propose a minimum age of $112.6 \mathrm{Ma}$, the Aptian-Albian boundary (113 $\pm 0.4 \mathrm{Ma}$; Ogg and Hinnov, 2012), for this fossil, based especially on palynological correlations by Heimhofer and Hochuli (2010).

Previous Use as Calibration. None to our knowledge. 


\section{Fossil Taxon 3 (additional)}

Archaeanthus linnenbergeri Dilcher and Crane, 1984

Node Calibrated. Stem Magnoliaceae (Doyle and Endress, 2010)

Reference Specimen. UF 15703-4152 in University of Florida, Gainesville, USA (holotype of Archaeanthus linnenbergeri Dilcher and Crane; multifollicular fruit and proximal reproductive and vegetative portions of the same axis).

Additional Specimens. UF 15703; 2300, 2317, 2318, 2590, 3022, 3837, 3907, 4105, 4112, 41344150, 4152, 4153, 4155-4158, 4163, 4164, 4166$4170,4198,4532-4534$ : other specimens of Archaeanthus linnenbergeri examined in Dilcher and Crane (1984).

UF 15703-3179 (holotype of Archaepetala beekeri Dilcher and Crane; perianth parts).

UF 15703-3882. Other specimen of Archaepetala beekeri examined in Dilcher and Crane (1984).

UF 15703-2266 (holotype of Archaepetala obscura Dilcher and Crane; perianth parts).

UF 15703-2747 (holotype of Kalymnanthus walkeri Dilcher and Crane; bud-scales).

UF 15703-4114, UF 15703-4115. Other specimens of Kalymnanthus walkeri examined in Dilcher and Crane (1984).

UF 15703-2272 (holotype of Liriophyllum kansense Dilcher and Crane; leaves).

UF 15703; 2267, 2271-2277, 2309, 2456, 24632466, 2469-2471, 2473, 2475-2477, 2479, 2480, 2482, 2484, 2485, 2487, 2488, 2492, 2493, 2679, $2948,3443,2813,3816-3818,3823,3826,3827$, 3836, 3839, 3859, 3885, 3886, 3890, 3894, 3895, 3992, 4028, 4029, 4051, 4120. Other specimens of Liriophyllum kansense examined in Dilcher and Crane (1984).

Phylogenetic Justification. The position of Archaeanthus linnenbergeri was investigated by Doyle and Endress (2010), in a molecular scaffold analysis in which the family Magnoliaceae (ca. 227 species) was split into two taxa: Magnolioideae, often treated by recent authors as the single genus Magnolia, and Liriodendron. This analysis placed Archaeanthus in three different most parsimonious positions: one as the sister group of Magnoliaceae as a whole, and two within crown-group Magnoliaceae, either sister to Liriodendron or sister to Magnolioideae. The clade of Archaeanthus and Magnoliaceae was supported by three unambiguous synapomorphies: sheathing leaf base, bilobed stipules, and elongate receptacle, while the positions within the family were supported by bilobed leaf apex (shared with Liriodendron) or dehiscent fruit (shared with Magnolioideae). By contrast, a recent cladistic analysis by Romanov and Dilcher (2013) positioned Archaeanthus sister to the Late Cretaceous seed genus Liriodendroidea (Frumin and Friis, 1996) and identified the clade made up of these two extinct genera as the sister group of Liriodendron, supported by four synapomorphies. This would imply that Archaeanthus provides a minimum age for crown-group Magnoliaceae. However, the taxonomic sampling of this analysis was very limited, as the extant taxa included only Magnoliaceae s.s. (= Magnolioideae) as a supraspecific terminal, Liriodendron, and Illicium (Austrobaileyales), which is many nodes more distant from Magnoliaceae than are other members of the order Magnoliales. In addition, one of the four proposed synapomorphies of Archaeanthus and Liriodendron, whorled perianth phyllotaxis, vs. spiral in Illicium and Magnolia, appears to be a symplesiomorphy in Magnoliales, where the perianth is basically whorled and trimerous (Endress and Doyle, 2009). Furthermore, although the perianth is spiral in some species of Magnolia s.l., in many species it is whorled (e.g., M. denudata: Erbar and Leins, 1981). Two other proposed synapomorphies, bilobed leaf apex and leaf lobation, are not independent characters, since the only lobation in the leaf of Archaeanthus is that of the apex; its origin requires only one change, not two. The status of the fourth synapomorphy, fruitlets shed from the receptacle, is uncertain, since Degeneria and most Annonaceae also have this feature (van Setten and Koek-Noorman, 1992). These observations imply that there are no more acceptable synapomorphies of Archaeanthus and Liriodendron in the Romanov and Dilcher (2013) data set than in Doyle and Endress (2010).

Even though we cannot dismiss the possibility that future analyses, based on denser taxon sampling and better knowledge of the phylogenetic position of Magnoliaceae, may eventually support a position of Archaeanthus within crown-group Magnoliaceae, we prefer to be conservative and recommend the use of Archaeanthus to serve as a minimum age constraint for the stem node of Magnoliaceae. In the current consensus tree presented in Figure 1, this is the same node as crown-group Magnoliinae (the larger clade of five families found by Doyle and Endress, 2010; Sauquet et al., 2003). However, this is not the case in one of the resolved trees of Massoni et al. (2014) on which this consensus tree is based, in which Magnoliaceae are the sister group of the clade consisting of Degeneria (Degeneriaceae) and Galbulimima (Himantand- 
raceae). Furthermore, maintaining a distinction between the two nodes may be useful because the association of Archaeanthus with Magnoliaceae appears to be more strongly supported than that of Endressinia (and Schenkeriphyllum) and less likely to change in future analyses.

Minimum Age. Early-middle Cenomanian boundary, $96.5 \mathrm{Ma}$

Age Justification. All the specimens used to describe Archaeanthus linnenbergeri come from the Dakota Formation at the Linnenberger Ranch in Russell County, central Kansas, USA (Dilcher and Crane, 1984). This formation lies between the underlying Kiowa Shale of Albian age and the overlying Graneros Shale (Retallack and Dilcher, 2012) of Cenomanian age. It has been traditionally divided into two members, the Terra Cotta Clay Member below and the Jansen Clay Member above (Plummer and Romary, 1942). The beds containing the specimens considered here were assigned to the Jansen Clay Member (Dilcher and Crane, 1984). Dilcher and Crane (1984) considered the age of this locality to be latest Albian to earliest Cenomanian. However, D.L. Dilcher (pers. comm. in Doyle and Endress, 2010) argued that it is more likely latest Albian, based on a carbon isotope and sequence stratigraphic study by Gröcke et al. (2006) at the Rose Creek locality in Nebraska, where a flora described by Upchurch and Dilcher (1990) lies just below the Albian-Cenomanian boundary, plus the fact that the Dakota is transgressive toward the east and sites such as Russell County are among its most western exposures. A latest Albian age was accepted by Doyle and Endress (2010) and reaffirmed without discussion by Romanov and Dilcher (2013). However, although the Rose Creek and Linnenberger Ranch floras were both assigned to the Jansen Clay Member and considered roughly coeval by Farley and Dilcher (1986), their equivalence needs reexamination in light of detailed sequence stratigraphic and palynological analyses of the Dakota Formation in Kansas, Nebraska, and lowa by Ludvigson et al. (2010). This study showed that the Dakota does not represent a simple transgressive sequence but rather three transgressive-regressive cycles. The first two cycles (equivalent to Palynostratigraphic Units 1 and 2) are late Albian, while the third (Units 3 and 4 ) is early and middle Cenomanian; the boundary recognized by Gröcke et al. (2006), between the second and third cycles, falls within beds formerly assigned to the Jansen Clay Member. Unfortunately, this analysis did not extend as far west as Russell County, although in Lincoln
County, just to the east, the lower part of the third cycle is represented by Dakota continental beds that interfinger with marine rocks to the west. Because we cannot exclude the possibility that the Linnenberger flora is from the lower part of the third cycle, which Ludvigson et al. (2010) dated as early Cenomanian, we propose a conservative minimum age of $96.5 \mathrm{Ma}$ for Archaeanthus, the early-middle Cenomanian boundary (no uncertainty provided; Ogg and Hinnov 2012).

Previous Use as Calibration. Archaeanthus has been used to provide calibration points within Magnoliidae in studies focused on angiosperms (Magallón and Castillo, 2009) and on Annonaceae (Doyle et al., 2004; Richardson et al., 2004; Pirie et al., 2006; Couvreur et al., 2008; Erkens et al., 2009; Su and Saunders, 2009; Pirie and Doyle, 2012). The great majority of these analyses used this fossil as a minimum age constraint of $98 \mathrm{Ma}$ for the node recommended in the present study (stem Magnoliaceae; Doyle et al., 2004; Richardson et al., 2004; Pirie et al., 2006; Couvreur et al., 2008; Erkens et al., 2009; Su and Saunders, 2009). Only Magallón and Castillo (2009) used the age we recommend (96.5 Ma), whereas Pirie and Doyle (2012) used an age of $100 \mathrm{Ma}$.

\section{NODE 2: CROWN-GROUP LAURALES}

\section{Fossil Taxon 4 (preferred, given current knowledge)}

Virginianthus calycanthoides Friis, Eklund, Pedersen and Crane, 1994

Node Calibrated. Crown-group Laurales (Doyle et al., 2008)

Reference Specimen. PP43703 in Field Museum of Natural History, Chicago (holotype; flower).

Phylogenetic Justification. Friis et al. (1994) assigned Virginianthus calycanthoides to the stem lineage of Calycanthaceae because it resembles extant Calycanthaceae (including Idiospermum) but is more plesiomorphic in characters such as monosulcate rather than disulculate pollen. This assignment was questioned by Crepet et al. (2005) based on a combined (total evidence) analysis of a data set of Renner (1999), which included 15 morphological characters, sequences of six molecular markers, 25 taxa of Laurales, and three outgroups. This analysis identified Virginianthus as the sister group of either Laurales as a whole or all Laurales other than Calycanthaceae. A molecular scaffold analysis by Doyle et al. (2008), incorporating 65 morphological characters and using the same backbone trees as Doyle and Endress (2010), 
found two alternative most parsimonious positions for this fossil, one sister to Calycanthaceae, the other sister to the clade formed by all remaining Laurales. The first position was supported by extended anther connective and the second by embedded pollen sacs. Positions sister to Laurales as a whole and nested within Calycanthaceae were one step less parsimonious. Here we follow the result of Doyle et al. (2008) because it is based on a data set that included far more characters than Crepet et al. (2005), many derived from indepth analyses of gynoecial morphology (e.g., Igersheim and Endress, 1997). Both most parsimonious positions imply that Virginianthus provides a minimum age for the crown node of Laurales (Figure 1).

Minimum Age. Middle-late Albian boundary, 107.7 $\mathrm{Ma}$

Age Justification. The fossil flower described by Friis et al. (1994) comes from the Potomac Group at the Puddledock locality in the Tarmac Lone Star Industries sand and gravel pit $9 \mathrm{~km}$ southwest of Hopewell, Prince George County, Virginia, USA. Friis et al. $(1994,1995)$ and von Balthazar et al. (2011) considered this locality early or middle Albian, based on palynological correlation by R.A. Christopher (in Dischinger, 1987) with the basal part of Potomac Subzone II-B of Brenner (1963) and Doyle and Robbins (1977) and the suggestion of Doyle (1992) that Subzone II-B may begin in the early Albian. However, an early Albian age for Subzone II-B (and II-A) now appears unlikely in light of palynological correlations by Hochuli et al. (2006) with the well-dated marine Lower Cretaceous of Portugal and earlier work of Kemp (1970) on the marine Albian of England (cf. Doyle et al., 2008). These studies support correlation of upper Zone I with the basal early Albian of Portugal and the early Albian of England, based on the appearance in all these intervals of reticulate tricolpate pollen and Clavatipollenites rotundus (aff. Retimonocolpites dividuus of Doyle and Robbins, 1977), as argued by Doyle and Robbins (1977), but not striate tricolpates, which appear later in the early Albian of Portugal (Hochuli et al., 2006). Consistent with this, the Zone II index spore species Apiculatisporis babsae of Brenner (1963) appears at the base of the middle Albian in England (Kemp, 1970). The conclusion of Doyle (1992) that the Zone I/II boundary lies well down in the Aptian was based largely on comparisons with Pennipollis (Brenneripollis) species and Schrankipollis in Africa that appear to have involved too indirect cor- relations and incompletely controlled species ranges, as argued by Hochuli et al. (2006).

Clarke et al. (2011) proposed a much younger minimum age for Puddledock, 92.7 Ma, or the top of the Cenomanian, based on the suggestion of Hochuli et al. (2006) that Zone II extends into the Cenomanian and the presence of late Cenomanian ammonites in the next younger unit, the Raritan Formation of New Jersey (Cobban and Kennedy, 1990). Hochuli et al. (2006) argued convincingly that there is a significant break between Zones I and II in the Potomac sequence, since the early to middle Albian interval in Portugal shows continuing higher diversity of angiosperm monosulcates than tricolpates, whereas tricolpates are already more diverse at the base of Zone II. They argued that Subzone II-B is late rather than middle Albian, based on the higher diversity of tricolpates than in the Portuguese middle Albian and the presence through Subzone II-B of the smooth tricolpate species Cupuliferoidaepollenites (Tricolpopollenites) parvulus, which they noted has not been reported in dated sequences until the late Albian. However, the reliability of $C$. parvulus is uncertain, since this species is rare in Subzone II-B and easy to overlook (for example, it was not reported by Brenner, 1963). Furthermore, its first occurrences cited by Hochuli et al. (2006) are in Canada, in the Northern Laurasia province of Brenner (1976), where angiosperms were less abundant than in Southern Laurasia, and in deep sea cores. It is also possible that the higher diversity of angiosperms observed in the Potomac is partly a facies effect of comparing continental and marginal marine sequences. If angiosperms were locally dominant in some lowland habitats but subordinate to ferns and gymnosperms at the regional scale (cf. Pierce, 1961; Doyle and Hickey, 1976), more angiosperms (including rare species) might be detected in a fluvial sequence such as the Potomac Group than in marine deposits like those in Portugal, where they would be diluted by the higher regional production of fern spores and gymnosperm pollen. It is also likely that the contrast between diversity curves from the two sequences is exaggerated by the fact that the Portuguese curves were based on number of species per sample, whereas the Potomac curves were based on a range chart (Doyle and Robbins, 1977), so that species whose ranges pass through the horizon of a given sample but were not found in that sample were treated as present.

More positive evidence that much of Subzone II-B is middle Albian comes from palynological cor- 
relations with well-dated sequences in the US Gulf Coast and Western Interior, which were not considered by Hochuli et al. (2006). Doyle (1977) showed that the diverse angiosperm flora in the middle of Subzone II-B is especially similar at the species level to that described by Hedlund and Norris (1968) in the "Walnut" Clay and Antlers Sand (Fredericksburgian) of Oklahoma, which lies below the middle-late Albian boundary defined by ammonites in the overlying Goodland Limestone (Hedlund and Norris, 1968; Mancini and Puckett, 2005). Doyle and Robbins (1977) dated Subzone II-C as latest Albian, but Hochuli et al. (2006) argued that it is Cenomanian, based on the psilate tricolporate species Tricolporoidites (Tricolporopollenites) distinctus and Tricolporoidites (Tricolporopollenites) triangulus, which they stated first appear in the Cenomanian. However, most of the studies that Hochuli et al. (2006) cited considered only Cenomanian beds, not the latest Albian. More important, Ludvigson et al. (2010) listed psilate tricolporates (as Psilatricolporites sp.) in the latest Albian (Palynostratigraphic Unit 2) of the Dakota Formation (see discussion of Archaeanthus, Fossil 3), and Laing (1975) recorded triangular grains similar to $T$. triangulus as Psilatricolpites rectilatibus in the marine upper Albian of France (Laing distinguished $P$. rectilatibus from $T$. triangulus on lack of pores, but the bent shape of the colpi in the Cenomanian grain illustrated in his plate 90 , figures $11-12$ suggests that rudimentary pores were present). Together, these correlations lead us to consider that Virginianthus is of middle Albian age. Therefore, we use the middle-late Albian boundary, 107.7 Ma (no uncertainty provided; Ogg and Hinnov, 2012), as a minimum age for Virginianthus.

Previous Use as Calibration. Virginianthus has been used in several large-scale studies (Magallón and Sanderson, 2005; Moore et al., 2007; Soltis et al., 2008; Bell et al., 2010). With the exception of Magallón and Sanderson (2005), who used this fossil to calibrate the crown node of Laurales with a minimum age of $110 \mathrm{Ma}$, all these analyses used it to calibrate the most recent common ancestor of Laurales and Magnoliales (i.e., the stem node of Laurales). Moore et al. (2007) used it to define a minimum age of $113 \mathrm{Ma}$, Soltis et al. (2008) an age fixed between 98 and $113 \mathrm{Ma}$, and Bell et al. (2010) a minimum age of $98 \mathrm{Ma}$. In order to date divergence times within Calycanthaceae, Zhou et al. (2006) used this species to calibrate the age of the stem node of the family as at least $112 \mathrm{Ma}$.

\section{Fossil Taxon 5 (additional)}

Lovellea wintonensis Dettmann, Clifford, and Peters, 2009

Node Calibrated. Crown-group Laurales (Dettmann et al., 2009)

Reference Specimen. QMF51133 in the Palaeontological Collection of the Queensland Museum, Queensland, Australia (Holotype, originally a complete specimen, now consisting of portions of a permineralized (silicified) flower/fruit in rock matrix cut longitudinally into two slices and two thin sections: QMF51133 a-d).

Additional Specimens. QMF51134, QMF51135, QMF51132. Other specimens used for the description (flowers/fruits).

Phylogenetic Justification. A morphological parsimony analysis using the matrix of Doyle and Endress (2000), with the exclusion of several taxa (eudicots, Piperales, Nymphaeales, monocots, Austrobaileya, Schisandraceae, and Illicium), placed Lovellea wintonensis in one most parsimonious position sister to all Laurales excluding Calycanthaceae (Dettmann et al., 2009). This "core Laurales" clade was well supported in previous studies (Soltis et al., 1999, 2000a, 2000b, 2007, 2011; Qiu et al., 1999, 2000, 2005, 2006, 2010; Renner, 1999, 2004; Doyle and Endress, 2000; Savolainen et al., 2000; Zanis et al., 2002, 2003; Nickrent et al., 2002; Hilu et al., 2003). Relationships within the clade based on the morphological analysis were not identical to those found in molecular or combined morphological and molecular analyses (Doyle and Endress, 2000), but they are consistent in supporting the monophyly of the Hernandiaceae-Lauraceae-Monimiaceae clade (though with the addition of Siparunaceae) and the position of Atherospermataceae and Gomortegaceae as outgroups to this clade (though as two successive branches rather than a clade). We consider Lovellea wintonensis to provide a minimum age for crown-group Laurales, or the stem node of all Laurales except Calycanthaceae (Figure 1).

Minimum Age. Albian-Cenomanian boundary, 100.1 Ma (100.5 $\pm 0.4 \mathrm{Ma})$

Age Justification. Lovellea wintonensis comes from the basal part of the the Winton Formation, 48 km WNW of Winton, western Queensland, Australia (Dettmann et al., 2009). Dettmann et al. (2009) placed the sediments containing these fossils in the Coptospora paradoxa or Phimopollenites pannosus spore-pollen Zones of Helby et al. (1987) based on the co-occurrence of Cicatricosisporites, Crybelosporites, Clavatipollenites, and Phimopollenites, indicating that they are no older than mid- 
dle Albian. Because the Winton Formation overlies the late Albian Mackunda Formation but no palynomorph taxa indicative of a Cenomanian or younger age are present, Dettmann et al. (2009) suggested a latest Albian age. Here we accept this age for Lovellea wintonensis and therefore use the upper boundary of the Albian, 100.1 Ma (100.5 $\pm 0.4 \mathrm{Ma}$; Ogg and Hinnov, 2012), as a safe minimum age for this fossil.

Previous Use as Calibration. None to our knowledge.

\section{NODE 3: CROWN-GROUP CALYCANTHOIDEAE}

\section{Fossil Taxon 6}

Jerseyanthus calycanthoides Crepet, Nixon and Gandolfo, 2005

Node Calibrated. Crown-group Calycanthoideae (Crepet et al., 2005)

Reference Specimen. CUPC 1483 in the Paleobotany Collection of the L.H. Bailey Hortorium, Cornell University (holotype / flower).

Additional Specimens. CUPC 1484-1502. Paratypes (flowers).

Phylogenetic Justification. Using the combined morphological and molecular data set described for Virginianthus (Fossil 4), in which Calycanthaceae were represented by Idiospermum, Chimonanthus, and Calycanthus, Crepet et al. (2005) found one most parsimonious position for Jerseyanthus calycanthoides, as the sister group of Calycanthus. Addition of the fossil Virginianthus calycanthoides did not influence the position of Jerseyanthus. The relationships among the three extant genera of Calycanthaceae are well supported in the literature, with Idiospermum sister to Chimonanthus and Calycanthus (Renner, 1998, 1999; Zhou et al., 2006; Massoni et al., 2014). Jerseyanthus calycanthoides therefore provides a minimum age for crown-group Calycanthoideae, the clade that is sister to Idiospermum and contains Chimonanthus and Calycanthus (Figure 1).

Minimum Age. Coniacian-Santonian boundary, 85.8 Ma (86.3 $\pm 0.5 \mathrm{Ma})$

Age Justification. These fossils were collected from the South Amboy Fire Clay Member of the Raritan Formation at the Old Crossman clay pit in Sayreville, New Jersey, USA (Crepet et al., 2005). This unit was first studied palynologically by Groot et al. (1961), who considered it Turonian based on preliminary studies on European sequences, and subsequently by Doyle (1969b), Wolfe and Pakiser (1971), Doyle and Robbins (1977), and Christopher (1979). Building on the palynological zonation of the Potomac Group by Brenner (1963), to which Doyle (1969a) added Zone III (uppermost Potomac) and Zone IV (lower Raritan), Sirkin (1974) assigned South Amboy palynofloras to a new Zone V. This unit was renamed the Complexiopollis exigua-Santalacites minor Zone by Christopher (1979) and redefined by Christopher et al. (1999) as the lowest of three subzones of the Sohlipollis Taxon Range Zone. Wolfe and Pakiser (1971) and Sirkin (1974) considered the South Amboy late Cenomanian, not much younger than underlying Woodbridge Clay Member (Zone IV), but Doyle (1969b) and Doyle and Robbins (1977) argued that it is no older than middle Turonian, based on the presence of Normapolles genera that appear at that level in Europe (Góczán et al., 1967). Doyle and Robbins (1977) and Christopher (1979) allowed that it was "possibly Coniacian," but Crepet and Nixon (1994) and Crepet et al. (2005) accepted a late Turonian age. By contrast, Clarke et al. (2011) suggested a minimum age of the Santonian-Campanian boundary, 82.8 Ma. However, correlations by Christopher et al. (1999) and Christopher and Prowell (2010) with better-dated rocks in South Carolina imply that the Crossman locality is not this young; they correlate the C. exigua-S. minor Zone with calcareous nannofossil zones CC13 and CC14, which extend from late Turonian through Coniacian (Burnett, 1998; Ogg and Hinnov, 2012). We therefore believe there is enough evidence to consider that Jerseyanthus was at least of Coniacian age, which translates into a conservative minimum age of $85.8 \mathrm{Ma}$, the ConiacianSantonian boundary (86.3 $\pm 0.5 \mathrm{Ma}$; Ogg and Hinnov, 2012).

Previous Use as Calibration. None to our knowledge.

\section{NODE 4: CROWN-GROUP CORE LAURALES}

\section{Fossil Taxon 7 (preferred, given current knowledge)}

Cohongarootonia hispida von Balthazar, Crane, Pedersen, and Friis, 2011

Node Calibrated. Crown-group core Laurales (the clade consisting of Laurales except Calycanthaceae) (von Balthazar et al., 2011)

Reference Specimen. PP53716 in the Field Museum of Natural History, Chicago (holotype, flower).

Phylogenetic Justification. A molecular scaffold analysis by von Balthazar et al. (2011), using the morphological data set from Doyle and Endress (2010) and one of the same backbone trees, in 
which Lauraceae and Hernandiaceae form a clade sister to Monimiaceae, placed Cohongarootonia hispida in a single most parsimonious position as the sister group of Lauraceae + Hernandiaceae. Synapomorphies of the three taxa were whorled tepals, whorled stamens, and one carpel. As a result, von Balthazar et al. (2011) unequivocally assigned the fossil to the order Laurales. However, although all recent analyses agree that Lauraceae, Hernandiaceae, and Monimiaceae form a well-supported clade within Laurales, the relationships among these three families are still debated. In analyses by Doyle and Endress (2000), a sister group relationship of Lauraceae and Hernandiaceae was strongly supported by morphological data and by combined morphological and molecular data, but analyses of molecular data alone have linked either Monimiaceae and Lauraceae or Monimiaceae and Hernandiaceae (Qiu et al., 1999, 2000, 2005, 2006, 2010; Renner, 1999; Doyle and Endress, 2000; Savolainen et al., 2000; Renner and Chanderbali, 2000; Hilu et al., 2003; Zanis et al., 2003; Soltis et al., 2011; Massoni et al., 2014). Until this conflict is resolved, we consider that Cohongarootonia hispida provides a minimum age for the stem node of the clade including Lauraceae, Monimiaceae, and Hernandiaceae, in other words the crown node of the clade of Laurales excluding Calycanthaceae (Figure 1).

Minimum Age. Middle-late Albian boundary, 107.7 Ma.

Age Justification. Cohongarootonia was collected from the Potomac Group at the same Puddledock locality, $9 \mathrm{~km}$ southwest of Hopewell, Virginia, as Virginianthus calycanthoides (Fossil 4). As discussed for that species, this locality has been correlated palynologically by R.A. Christopher (in Dischinger, 1987) with the lower part of Subzone IIB of Brenner (1963), which we argue is of middle Albian age. Therefore, we use the middle-late Albian boundary, 107.7 Ma (no uncertainty provided; Ogg and Hinnov, 2012), as a minimum age for Cohongarootonia.

Previous Use as Calibration. None to our knowledge.

\section{Fossil Taxon 8 (additional)}

Mauldinia mirabilis Drinnan, Crane, Friis and Pedersen, 1990

Node Calibrated. Crown-group core Laurales (the clade consisting of Laurales except Calycanthaceae) (Doyle and Endress, 2010)
Reference Specimen. PP35297 in Field Museum of Natural History, Chicago, USA (holotype of Mauldinia mirabilis; inflorescence).

Additional Specimens. PP34733, PP34794, PP34796, PP34797, PP35002-PP35006, PP35008, PP35056, PP35061, PP35141, PP35295-PP35305, PP35338-PP35340. Other specimens of Mauldinia mirabilis cited in Drinnan et al. (1990) (inflorescence fragments with flowers). PP34709-PP34715, PP34728-PP34732, PP34779, PP34780, PP34926, PP34927, PP34929, PP35007, PP35016-PP35019, PP35051-PP35055, PP35057-PP35060, PP35140, PP35150, PP35151, PP35306PP35309, PP35315-PP35319. Other specimens of Mauldinia mirabilis cited in Drinnan et al. (1990) (flowers).

P34903-PP34925, PP35009, PP35050, PP35144. Other specimens of Mauldinia mirabilis cited in Drinnan et al. (1990) (dispersed stamens).

PP34781-PP34783, PP34795, PP34928, PP34930, PP34931, PP35010-PP35012, PP35142, PP35143. Other specimens of Mauldinia mirabilis cited in Drinnan et al. (1990) (dispersed carpels).

PP34932, PP34933, PP35024, PP35025, PP35026, PP42982, PP42983. Other specimens of Mauldinia mirabilis cited in Drinnan et al. (1990) (cuticle preparations).

PP42981. Other specimens of Mauldinia mirabilis cited in Drinnan et al. (1990) (unsorted fragments). PP35023 (holotype of Paraphyllanthoxylon marylandense Herendeen, 1991; mature wood).

PP43591, PP43592, PP43617, PP43619, PP43620, PP43621, PP43622, PP43624, PP43625, PP43627, PP43629, PP43630, PP43631, PP43632, PP43636. Paratypes of Paraphyllanthoxylon marylandense Herendeen, 1991 (mature wood).

Phylogenetic Justification. Because of identical features in the first formed wood of Paraphyllanthoxylon marylandense (Herendeen, 1991) and inflorescence axes of Mauldinia mirabilis (Drinnan et al., 1990), Doyle and Endress (2010) combined these two taxa in their analyses. Their molecular scaffold analysis, which used a backbone tree in which Lauraceae and Hernandiaceae formed a clade sister to Monimiaceae, placed this fossil in a single most parsimonious position, as the sister group of Lauraceae + Hernandiaceae. The three taxa were united by the following unequivocal synapomorphies: solitary vessels, inflorescences with lateral cymes, whorled tepals, whorled stamens, and one carpel. The basal position of Mauldinia rel- 
ative to the two living taxa was supported by the absence of well-developed paratracheal parenchyma in the wood, the superior position of the ovary, and the presence of endosperm in the seed, while Lauraceae and Hernandiaceae are united by paratracheal parenchyma, an inferior ovary (reversed within Lauraceae: Rohwer and Rudolph, 2005), and lack of endosperm in the mature seed. A position sister to Lauraceae alone was four steps less parsimonious. However, as discussed for Cohongarootonia (Fossil 7), Lauraceae and Hernandiaceae are included together with Monimiaceae in a well-supported clade, but different analyses have found all possible relationships among the three families. When Doyle and Endress (2010) used a molecular backbone in which Monimiaceae were sister to Lauraceae, the single most parsimonious position of Mauldinia was sister to the whole clade of Hernandiaceae + Lauraceae + Monimiaceae. Doyle and Endress (2010) did not test the third alternative present in the literature (Lauraceae sister to the remaining two families), but using their data set we find that the most parsimonious position for Mauldinia under this arrangement is also sister to the three living taxa. Until this conflict is resolved, we consider Mauldinia mirabilis to provide a minimum age for the stem node of the clade of Lauraceae, Hernandiaceae, and Monimiaceae, in other words the crown node of the clade of Laurales excluding Calycanthaceae (Figure 1).

Minimum Age. Middle-late Cenomanian boundary, $95.5 \mathrm{Ma}$

Age Justification. Mauldinia mirabilis and Paraphyllanthoxylon marylandense were described from the Mauldin Mountain locality in the upper Potomac Group ("Maryland Raritan") of northeastern Maryland, USA (Drinnan et al., 1990; Herendeen, 1991). These beds contain a palynoflora assigned to the lower part of Zone III of the Potomac sequence, which Doyle and Robbins (1977) dated as early Cenomanian. The age of Zone III is bracketed above by the appearance of triporate Normapolles pollen (Complexiopollis spp.) in the lower Raritan Formation of New Jersey (Zone IV) and the upper part of the Peruc Formation of Bohemia (Pacltová, 1971; Doyle and Robbins, 1977), and by late Cenomanian ammonites in the lower Raritan (Cobban and Kennedy, 1990). The Peruc Formation underlies marine sediments with late Cenomanian mollusks, and its upper part was correlated palynologically by Pacltová (1977) with late middle Cenomanian marine beds that contain the first Normapolles in England and France (Azéma et al., 1972; Laing, 1975); this agrees with studies of sequence stratigraphy in the Bohemian section by Uličný et al. (1997). The probable latest Albian age of Potomac Subzone II-C is discussed under Virginanthus. Because these data imply that the Zone III-IV boundary may lie within the middle Cenomanian, and the length of time between the base and top of Zone III is uncertain, it appears safest to conclude that Mauldinia could be of either early or middle Cenomanian age. Therefore, we propose the middle-late Cenomanian boundary, 95.5 Ma (no uncertainty provided; Ogg and Hinnov, 2012), as a conservative minimum age for Mauldinia.

Previous Use as Calibration. None to our knowledge.

\section{NODE 5: CROWN-GROUP CANELLALES}

\section{Fossil Taxon 9}

Walkeripollis gabonensis Doyle, Hotton, and Ward, 1990

Node Calibrated. Crown-group Canellales (Doyle and Endress, 2010)

Reference Specimen. Single-pollen grain preparation 2963-27 (holotype of Walkeripollis gabonensis). Doyle et al. (1990) stated that this specimen is deposited in the Elf-Aquitaine collection, but it is on Ioan to J.A. Doyle at the University of California, Davis. Because the company Elf-Aquitaine no longer exists, it will be deposited at the University of California (Berkeley) Museum of Paleontology (UCMP).

Additional Specimens. Sections, uncut block, and negatives, from Elf-Aquitaine preparation 2963, TM.1 (N'Toum No. 1) well, core 8, 939-944 $\mathrm{m}$, Subzone C-VIlc, Gabon.

Phylogenetic Justification. Use of fossil pollen for calibration can be questioned because it usually lacks sufficient characters for secure phylogenetic placement, but this taxon has such a unique combination of features that it could be unambiguously placed in a large-scale phylogenetic analysis. A molecular scaffold analysis placed Walkeripollis gabonensis in a single most parsimonious position as sister to Winteraceae (Doyle and Endress, 2010), one of the two families of Canellales. Synapomorphies supporting this sister-group relationship were permanent tetrads and round aperture shape. The sculpture on the pore, forming a ring around a central thin area, also suggests a close relationship between the fossil species and Winteraceae (Doyle and Endress, 2010). However, this character was not included in the Doyle and Endress (2010) data set because it was not appli- 
cable to most taxa. The sister-group relationship between living Winteraceae and Canellaceae is very well supported in the literature (e.g., Chase et al., 1993; Zanis et al., 2002, 2003; Qiu et al., 2005, 2006; Marquínez et al., 2009). We therefore consider Walkeripollis gabonensis to provide a minimum age for crown-group Canellales (Figure 1).

Minimum Age. Barremian-Aptian boundary, 125.9 Ma (126.3 $\pm 0.4 \mathrm{Ma})$

Age Justification. Walkeripollis gabonensis comes from the upper part of Elf-Aquitaine palynological Zone C-VII (Subzone C-VIIc) in the Cocobeach sequence (Doyle et al., 1990), near the town N'Toum in northern Gabon. The age of Zone C-VII is bracketed by late Aptian marine fossils in overlying units (Doyle et al., 1977, 1990). Doyle et al. $(1977,1982)$ dated Zone C-VII as early Aptian, but Doyle et al. (1990) and Doyle (1992) suggested it may be late Barremian, based on the occurrence of other taxa that appear in Zone C-VII, correlative rocks in Brazil, and better-dated Barremian rocks elsewhere, notably Afropollis and the first reticulate tricolpates (Doyle et al., 1982; Gübeli et al., 1984; Penny, 1989; Regali and Viana, 1989; Doyle, 1992). Additional evidence that favors a pre-Aptian age is the absence in Zone C-VII of two groups that appear in the overlying Zones C-VIII and C-IX and the Aptian of Egypt, namely striate tricolpates, which are not known until the Albian in Southern Laurasia but occur earlier in Northern Gondwana (Penny, 1988a; Hochuli et al., 2006; Heimhofer et al., 2007; Heimhofer and Hochuli, 2010), and the non-columellar reticulate monosulcate genus Pennipollis ("Retimonocolpites" peroreticulatus, etc.), which appears just above the base of the marine Aptian of England and has never been reported from well-dated pre-Aptian rocks (Penny, 1988b; Doyle, 1992; Hughes, 1994; Hochuli et al., 2006). We therefore believe it is safe to accept a late Barremian age for Walkeripollis gabonensis and thus propose $125.9 \mathrm{Ma}$, the upper boundary of the Barremian (126.3 $\pm 0.4 \mathrm{Ma}$; Ogg and Hinnov, 2012), as a minimum age for this fossil.

Previous Use as Calibration. Magallón (2010) and Magallón et al. (2013) used Walkeripollis to provide a minimum age of $125 \mathrm{Ma}$ for the same node recommended here (crown-group Canellales). Marquínez et al. (2009) used this fossil to fix the age of the crown node of Winteraceae at 120 Ma.

\section{NODE 6: STEM NODE OF EXTANT SAURURUS}

\section{Fossil Taxon 10}

Saururus tuckerae Smith and Stockey, 2007

Node Calibrated. Stem node of extant Saururus (Smith and Stockey, 2007)

Reference Specimen. P1631 Bbot a in the University of Alberta (Edmonton) Paleobotanical Collections (UAPC) (holotype; inflorescence).

Additional Specimens. P1631 Btop a, Btop b, Btop f, Btop h, Bbot c, Cbot e; P5831 Bbot; P5839 A; P5937 Gbot b; P5991 B. Paratypes (isolated flowers).

Phylogenetic Justification. A morphological parsimony analysis using 24 morphological characters modified from matrices of Tucker et al. (1993), Tucker and Douglas (1996), and Meng et al. (2003) placed Saururus tuckerae in a single most parsimonious position within the family Saururaceae, as the sister group of a clade formed by the two extant species of Saururus (Smith and Stockey, 2007). The relationship of the fossil with extant Saururus, one of four genera in Saururaceae, was supported by the following synapomorphies: basally connate carpels, 1-2 ovules per carpel, and marginal placentation (Smith and Stockey, 2007). This study indicated that the genus Saururus was sister to Gymnotheca, and Anemopsis was sister to Houttuynia, relationships supported by other molecular and morphological studies (Meng et al., 2002, 2003; Jaramillo et al., 2004; Neinhuis et al., 2005; Wanke et al., 2007b; Massoni et al., 2014). Outside the Saururaceae, the relationships are compatible with molecular studies (e.g., Qiu et al., 2005, 2006; Soltis et al., 1999, 2000a, 2000b, 2007, 2011; Mathews and Donoghue, 1999, 2000; Qiu et al., 1999, 2000; Doyle and Endress, 2000; Savolainen et al., 2000; Zanis et al., 2002, 2003; Borsch et al., 2003; Hilu et al., 2003; Kelly and González, 2003; Jaramillo et al., 2004; Wanke et al., 2007a, 2007b; Massoni et al., 2014). We thus consider Saururus tuckerae to provide a minimum age for the stem node of the extant genus Saururus, which is also the crown node of Gymnotheca + Saururus (Figure 1).

Minimum Age. 44.3 Ma

Age Justification. Fossils described by Smith and Stockey (2007) come from the Princeton Chert, 8.4 $\mathrm{km}$ south of Princeton, British Columbia, Canada, which is part of the Princeton Group, Allenby Formation (Boneham, 1968). The Princeton Chert consists of a series of alternating layers of coal and chert. The paleontological record supports a middle Eocene age, such as an amiid fish correlated 
with the occurrence of comparable fossils in British Columbia and in the Klondike Mountain Formation of Washington State (Wilson, 1982), and teeth of the mammal group Tillodontia (Russell, 1935). In addition, potassium-argon dating studies have provided comparable ages for the Allenby Formation: $48 \pm 2 \mathrm{Ma}$ (Rouse and Mathews, 1961; Mathews, 1964), between $47 \pm 2$ and $50 \pm 2 \mathrm{Ma}$ (Hills and Baadsgaard, 1967), and 46.2 $\pm 1.9 \mathrm{Ma}$ and $49.4 \pm$ $2 \mathrm{Ma}$ (Read, 2000). With a different method (U-Pb age from zircons), Moss et al. (2005) suggested an age of $52.08 \pm 0.12 \mathrm{Ma}$ for the Allenby Formation. Finally, Smith and Stockey (2007) report a personal communication from $\mathrm{H}$. Baadsgaard (University of Alberta, 1999) that supports an age of 48.7 Ma for the ash of Layer \#22 of the Princeton Chert. Because the $7.5 \mathrm{~m}$ of the Princeton Chert sequence (incorporating the layer where the fossil was collected) may have accumulated in 15,000 years or less (Mustoe, 2011), this latter age is probably the closest to the real age of the fossil. However, in order to be conservative regarding the uncertainty of the age of this formation, and the fact that no uncertainty is associated with the latter age, Saururus tuckarae provides a safe minimum age of $44.3 \mathrm{Ma}$ (the youngest age given by potassium-argon dating minus the associated error of 1.9 Ma).

Previous Use of this Fossil. González et al. (2014) used Saururus tuckerae to constrain the same node as recommended here, but with a minimum age of $48.5 \mathrm{Ma}$.

\section{DISCUSSION}

The 10 fossils reviewed in this study provide minimum age constraints on six internal nodes in the phylogeny of Magnoliidae (Table 1, Figure 1). Considered together, one of these age constraints (the crown node of Laurales) is uninformative because it is implied by an equal minimum age constraint nested higher in the tree. Six of these fossils have not yet been used to provide calibration points in any molecular dating studies. The four remaining have been used in several previous studies, often with different ages and to calibrate different nodes (see "Previous Use as Calibration" sections). Several other fossils have been used in the literature to set minimum age calibrations, some of which are different from those recommended here. In the majority of these papers the justification for a specific age and position used in association with these fossils was not provided. The present review is intended to be a reliable source of information for readers about the bases underlying the use of these calibration points.

The positions of Archaeanthus linnenbergeri, Endressinia brasiliana, Virginianthus calycanthoides, Mauldinia mirabilis, Cohongarootonia hispida, and Walkeripollis gabonensis have been evaluated using similar backbone trees and either the data set of Endress and Doyle (2009) or the data set of Doyle and Endress (2010) (see fossil sections $1,3,4,7,8$, and 9 for details). These studies investigated the position of the fossils in a broad context of basal angiosperms compatible with current knowledge of angiosperm phylogeny, and using a compromise between 'exemplar' and 'compartmentalized' approaches to taxon representation. When a supra-specific group did not have a homogeneous morphology, the authors of these studies filled the matrix with ancestral states deduced from knowledge of basal relationships in the taxon supported by other studies. Relationships within the compartments of Magnoliidae used by Endress and Doyle (2009) and Doyle and Endress (2010) to deduce plesiomorphic traits of these supra-specific terminals have not been contradicted by subsequent studies focused on particular families (Marquínez et al., 2009; Michalak et al., 2010; Renner et al., 2010; Chatrou et al., 2012). For all these reasons, we argue that the positions of the fossils supported in these studies are up-to-date and can be used with some confidence. Regarding other calibration points, the phylogenetic analyses we have used as a reference for fossil relationships in this paper represent solid advances. However, future analyses with denser taxon sampling and updated morphological and molecular data sets will be required to challenge further, and hopefully confirm, the relationships summarized in this paper. For instance, the analysis of Saururus tuckerae by Smith and Stockey (2007) could be improved by adding key taxa of Piperales not included in their analysis (Hydnoraceae, Thottea, Saruma, Manekia, and Verhuellia).

All the fossil species incorporated in our calibration scheme presented the advantage of having enough informative characters to allow accurate phylogenetic placement. However, because such fossils are not well represented in the fossil record, the delay between the time of divergence of the taxon and the fossilization event of the specimen used in the present study is difficult to estimate. Bayesian relaxed clock methods allow calibrations to be modeled with parametric distributions (uniform, exponential, lognormal, and gamma priors). These various priors are often used to model the 
probability that the node calibrated is older than the fossil used. However, given the difficulty in objectively setting parameters for these models in many empirical situations, as well as the phylogenetic uncertainty often associated with fossil relationships (leading to conservative calibration of the lowest safe node on the tree), Sauquet et al. (2012) recommended the use of uniform priors. For the present calibration scheme we agree with this point of view and recommend that our age constraints be used as strict minimum ages only. This issue, resulting from the sporadic preservation of extinct species in the fossil record, is exacerbated by the fact that different events of fossilization do not necessarily conserve the same part of the plant. Fortunately, in some cases, such as Archaeanthus linnenbergeri, morphological features have allowed safe identification of separate organs as parts of the same plant species. The association of different parts could lead to an older age associated with a fossil taxon. For instance, it is likely that Mauldinia or related plants extend down below the Albian-Cenomanian boundary, as leaves described as Pandemophyllum from the latest Albian Rose Creek locality in the Dakota Formation of Nebraska (Upchurch and Dilcher, 1990; Gröcke et al., 2006) may represent plants like those that produced fossils described as Prisca by Retallack and Dilcher (1981) from the Hoisington and Linnenberger Ranch localities in Kansas (see Archaeanthus), which are probably inflorescences of Mauldinia (Drinnan et al., 1990). In other cases, there are slightly younger fossils that are even more like the putative extant relatives of the fossils used here. This is true for Walkeripollis, where tetrads with similar aperture structure but more open reticulate sculpture, approaching modern Winteraceae, are known from Aptian-Albian beds of Israel (Walker et al., 1983; Schrank, 2013) and the late AlbianCenomanian of Argentina (Barreda and Archangelsky, 2006).

In addition to the 10 fossils listed here many more fossil taxa have been described as belonging to Magnoliidae, and a number of them could complement the current calibration set, pending further work on their phylogenetic relationships. There are species that are or bear flowers preserved in the form of compressions (e.g., Mohr and Eklund, 2003; Frumin et al., 2004), in three dimensions as charcoal (e.g., Kvaček and Eklund, 2003; Viehofen et al., 2008), or in amber (e.g., Poinar and Chambers, 2005). In addition to fossil flowers, there are fossil woods (e.g., Poole and Gottwald, 2001) and leaves (e.g., Rüffle and Knappe, 1988). Finally, pol- len grains, seeds, and fruits referred to the group are also common in the fossil record (e.g., Friis, 1985; Carpenter et al., 1994; Friis et al., 1995). Among these extinct species several could be very useful to supplement our set of calibration points; those based on isolated organs may have too few characters for unambiguous placement, but the situation might improve with better understanding of character distributions in the living flora or association with other organs. In our scheme, the Piperales have only one minimum age constraint, in contrast to several for Laurales and Magnoliales. For Aristolochiaceae there are several fossil leaf and wood taxa described from the Late Cretaceous (e.g., Kulkarni and Patil, 1977) and the Cenozoic (e.g., MacGinitie, 1974), which if confirmed could provide a minimum age of Late Cretaceous for the Piperales. Lactoripollenites africanus, a fossil pollen type of monoporate tetrads from TuronianCampanian sediments of the southern coast of southern Africa, was associated with the monotypic extant genus Lactoris by Zavada and Benson (1987). This fossil could also support the origin of the Aristolochiaceae in the Late Cretaceous. The 10 fossils reviewed in the present paper are generally close to the first reports of their taxonomic groups in the fossil record. However, Saururus nipponensis (Stopes and Fujii, 1911), interpreted as a fossilized stem of Saururaceae, from the Upper Cretaceous of Hokkaido (Japan), could provide much an older minimum age for the stem node of Saururaceae than the one used in the present review. Several fossils containing pollen grains in situ and sometimes branching axes bearing floral organs and leaves (e.g., Crepet and Nixon, 1998; Mohr and Eklund, 2003) would be good candidates for accurate phylogenetic placement. The latter cases are very interesting because they provide characters from different parts of the plant, without the uncertainty of association of two separate structures found in the same fossil bed. Several other fossils that are exceptionally well preserved could provide enough characters for an accurate phylogenetic placement within families. For instance, Lauranthus futabensis is a complete flower described from the lower Coniacian of the Futuba Group in northeastern Japan that has been interpreted as a member of Lauraceae (Takahashi et al., 2001).

Our new set of calibration points is a first step toward investigating the time scale of evolution of Magnoliidae as a whole more accurately than has been done before. Previous molecular dating analyses of Magnoliidae have been carried out either at 
an intra-ordinal level (e.g., Chanderbali et al., 2001; Doyle et al., 2004; Pirie et al., 2006; Smith et al., 2008; Marquínez et al., 2009; Pirie and Doyle, 2012) or at the level of angiosperms and higher (e.g., Bell et al., 2005, 2010; Moore et al., 2007; Soltis et al., 2008; Magallón and Castillo, 2009; Magallón, 2010; Smith et al., 2010). A maximum of six calibration points have been used so far within the group (Magallón and Castillo, 2009). In terms of taxonomic sampling, the most complete molecular dating studies including Magnoliidae as a whole incorporated about 11 percent of the generic diversity of Magnoliidae (Wikström et al., 2001; Moore et al., 2007; Soltis et al., 2008). Previous dating analyses have provided dates for the origin of the Magnoliidae ranging from the Early Jurassic to the Early Cretaceous (Wikström et al., 2001; Bell et al., 2005, 2010; Moore et al., 2007, 2010; Soltis et al., 2008; Magallón and Castillo, 2009; Magallón, 2010; Smith et al., 2010). Among subgroups of Magnoliidae, several published ages are not compatible with minimum calibration points provided here. For instance, Bell et al. (2010) found younger ages for the diversification of Canellales (50-111 $\mathrm{Ma}$ ) and Magnoliales (50-96 Ma), which are dated as at least 125.9 Ma and 112.6 Ma, respectively, by the present calibration scheme. A new molecular dating study of Magnoliidae, using this calibration scheme and denser taxonomic sampling, will certainly provide new insights on the tempo of the evolutionary history of this important group of angiosperms. In the future, a new morphological data set capturing the whole diversity of Magnoliidae would be very useful for filling in and improving the present calibration scheme. Such a data set, which we are currently assembling, will allow us to test and refine the phylogenetic placements of the fossils presented here and to evaluate the phylogenetic position of other described fossils.

\section{ACKNOWLEDGMENTS}

We thank N. Jud, S. Little, S. Smith, and G. Upchurch for data that helped us in preparing this manuscript. A. Antonelli, D. Kspeka, L. Hermsen, and M.A. Gandolfo are thanked for discussions and support of this study. D. Polly and two anonymous reviewers are also acknowledged for their helpful comments on this paper. This work was funded by a grant from Agence Nationale de la Recherche to H.S. (ANR-12-JVS7-0015-01).

\section{REFERENCES}

APG III. 2009. An update of the Angiosperm Phylogeny Group classification for the orders and families of flowering plants: APG III. Botanical Journal of the Linnean Society, 161:105-121.

Azéma, C., Durand, S., and Médus, J. 1972. Des miospores du Cénomanien moyen. Paléobiologie Continentale, 3:1-54.

Barreda, V. and Archangelsky, S. 2006. The southernmost record of tropical pollen grains in the mid-Cretaceous of Patagonia, Argentina. Cretaceous Research, 27:778-787.

Bell, C.D., Soltis, D.E., and Soltis, P.S. 2005. The age of the angiosperms: a molecular timescale without a clock. Evolution, 59:1245-1258.

Bell, C.D., Soltis, D.E., and Soltis, P.S. 2010. The age and diversification of the angiosperms re-revisited. American Journal of Botany, 97:1296-303.

Boneham, R.F. 1968. Palynology of three Tertiary coal basins in south central British Columbia. Unpublished $\mathrm{PhD}$ Thesis, University of Michigan, Ann Arbor, Michigan, USA.

Borsch, T., Hilu, K.W., Quandt, D., Wilde, V., Neinhuis, C., and Barthlott, W. 2003. Noncoding plastid trnTtrnF sequences reveal a well resolved phylogeny of basal angiosperms. Journal of Evolutionary Biology, 16:558-576.

Brenner, G.J. 1963. The spores and pollen of the Potomac Group of Maryland. Maryland Department of Geology, Mines and Water Resources Bulletin, 27:1215.

Brenner, G.J. 1976. Middle Cretaceous floral provinces and early migrations of angiosperms, p. 23-47. In Beck, C.B. (ed.), The Origin and Early Evolution of Angiosperms. Columbia University Press, New York.

Burleigh, J.G., Hilu, K.W., and Soltis, D.E. 2009. Inferring phylogenies with incomplete data sets: a 5-gene, 567-taxon analysis of angiosperms. BMC Evolutionary Biology, 9:61.

Burnett, J.A. 1998. Upper Cretaceous, p. 132-199. In Bown, P.R. (ed.), Calcareous Nannofossil Biostratigraphy. Chapman \& Hall, London.

Carpenter, R.J., Hill, R.S.S., and Jordan, G.J. 1994. Cenozoic vegetation in Tasmania: macrofossil evidence, p. 276-298. In Hill, R.S. (ed.), History of the Australian Vegetation. Cambridge University Press, Cambridge, UK.

Chanderbali, A.S., van der Werff, H., and Renner, S.S. 2001. Phylogeny and historical biogeography of Lauraceae: evidence from the chloroplast and nuclear genomes. Annals of the Missouri Botanical Garden, 88:104-134.

Chase, M.W., Soltis, D.E., Olmstead, R.G., Morgan, D., Les, D.H., Mishler, B.D., Duvall, M.R., Price, R.A., Hills, H.G., Qiu, Y.-L., Kron, K.A., Rettig, J.H., Conti, E., Palmer, J.D., Manhart, J.R., Sytsma, K.J., Michaels, H.J., Kress, W.J., Karol, K.G., Clark, W.D., Hedren, M., Gaut, B.S., Jansen, R.K., Kim, K.-J., Wimpee, C.F., Smith, J.F., Furnier, G.R., Strauss, 
S.H., Xiang, Q.-Y., Plunkett, G.M., Soltis, P.S., Swensen, S.M., Williams, S.E., Gadek, P.A., Quinn, C.J., Eguiarte, L.E., Golenberg, E., Learn, G.H., Graham, S.W., Barrett, S.C.H., Dayanandan, S., and Albert, V.A. 1993. Phylogenetics of seed plants: an analysis of nucleotide sequences from the plastid gene rbcL. Annals of the Missouri Botanical Garden, 80:528-548+550-580.

Chatrou, L.W., Pirie, M.D., Erkens, R.H.J., Couvreur, T.L.P., Neubig, K.M., Abbott, J.R., Mols, J.B., Maas, J.W., Saunders, R.M.K., and Chase, M.W. 2012. A new subfamilial and tribal classification of the pantropical flowering plant family Annonaceae informed by molecular phylogenetics. Botanical Journal of the Linnean Society, 169:5-40.

Christopher, R.A. 1979. Normapolles and triporate pollen assemblages from the Raritan and Magothy Formations (Upper Cretaceous) of New Jersey. Palynology, 3:73-121.

Christopher, R.A. and Prowell, D.C. 2010. A palynological biozonation for the uppermost Santonian and Campanian Stages (Upper Cretaceous) of South Carolina, USA. Cretaceous Research, 31:101-129.

Christopher, R.A., Self-Trail, J.M., Prowell, D.C., and Gohn, G.S. 1999. The stratigraphic importance of the Late Cretaceous pollen genus Sohlipollis gen. nov. in the Coastal Plain Province. South Carolina Geology, 41:27-44.

Clarke, J.T., Warnock, R.C.M., and Donoghue, P.C.J. 2011. Establishing a time-scale for plant evolution. New Phytologist, 192:266-301.

Cobban, W.A. and Kennedy, W.J. 1990. Upper Cenomanian ammonites from the Woodbridge Clay Member of the Raritan Formation in New Jersey. Journal of Paleontology, 64:845-846.

Coimbra, J.C., Arai, M., and Carreño, A.L. 2002. Biostratigraphy of Lower Cretaceous microfossils from the Araripe basin, northeastern Brazil. Geobios, 35:687698.

Couvreur, T.L.P., Chatrou, L.W., Sosef, M.S.M., and Richardson, J.E. 2008. Molecular phylogenetics reveal multiple tertiary vicariance origins of the African rain forest trees. BMC Biology, 6:54.

Couvreur, T.L.P., Pirie, M.D., Chatrou, L.W., Saunders, R.M.K., Su, Y.C.F., Richardson, J.E., and Erkens, R.H.J. 2011. Early evolutionary history of the flowering plant family Annonaceae: steady diversification and boreotropical geodispersal. Journal of Biogeography, 38:664-680.

Crepet, W.L. and Nixon, K.C. 1994. Flowers of Turonian Magnoliidae and their implications. Plant Systematics and Evolution, 8:73-91.

Crepet, W.L. and Nixon, K.C. 1998. Two new fossil flowers of magnoliid affinity from the Late Cretaceous of New Jersey. American Journal of Botany, 85:12731288.
Crepet, W.L., Nixon, K.C., and Gandolfo, M.A. 2005. An extinct calycanthoid taxon, Jerseyanthus calycanthoides, from the Late Cretaceous of New Jersey. American Journal of Botany, 92:1475-85.

Dettmann, M.E., Clifford, H.T., and Peters, M. 2009. Lovellea wintonensis gen. et $\mathrm{sp}$. nov.- Early Cretaceous (late Albian), anatomically preserved, angiospermous flowers and fruits from the Winton Formation, western Queensland, Australia. Cretaceous Research, 30:339-355.

Dilcher, D.L. and Crane, P.R. 1984. Archaeanthus: an early angiosperm from the Cenomanian of the western interior of North America. Annals of the Missouri Botanical Garden, 71:351-383.

Dischinger, J.B. 1987. Late Mesozoic and Cenozoic stratigraphic and structural framework near Hopewell, Virginia. U.S. Geological Survey Bulletin, 1567:1-48.

Doyle, J.A. 1969a. Angiosperm pollen evolution and biostratigraphy of the basal Cretaceous formations of Maryland, Delaware, and New Jersey (abs.). Geological Society of America Abstracts with Programs, $1: 51$.

Doyle, J.A. 1969b. Cretaceous angiosperm pollen of the Atlantic Coastal Plain and its evolutionary significance. Journal of the Arnold Arboretum, 50:1-35.

Doyle, J.A. 1977. Spores and pollen: the Potomac Group (Cretaceous) angiosperm sequence, p. 339-363. In Kauffman, E.G. and Hazel, J.E. (ed.), Concepts and Methods of Biostratigraphy. Dowden, Hutchinson \& Ross, Stroudsburg, PA, USA.

Doyle, J.A. 1992. Revised palynological correlations of the lower Potomac Group (USA) and the Cocobeach sequence of Gabon (Barremian-Aptian). Cretaceous Research, 13:337-349.

Doyle, J.A. and Endress, P.K. 2000. Morphological phylogenetic analysis of basal angiosperms: comparison and combination with molecular data. International Journal of Plant Sciences, 161, supplement:S121S153.

Doyle, J.A. and Endress, P.K. 2010. Integrating Early Cretaceous fossils into the phylogeny of living angiosperms: Magnoliidae and eudicots. Journal of Systematics and Evolution, 48:1-35.

Doyle, J.A. and Hickey, L.J. 1976. Pollen and leaves from the mid-Cretaceous Potomac Group and their bearing on early angiosperm evolution, p. 139-206. In Beck, C.B. (ed.), Origin and Early Evolution of Angiosperms. Columbia University Press, New York.

Doyle, J.A. and Robbins, E.I. 1977. Angiosperm pollen zonation of the continental Cretaceous of the Atlantic Coastal Plain and its application to deep wells in the Salisbury Embayment. Palynology, 1:41-78.

Doyle, J.A., Endress, P.K., and Upchurch, G.R. 2008. Early Cretaceous monocots: a phylogenetic evaluation. Acta Musei Nationalis Pragae Series B - Historia Naturalis, 64:61-89. 
Doyle, J.A., Hotton, C.L., and Ward, J. V. 1990. Early Cretaceous tetrads, zonasulculate pollen, and Winteraceae. I. Taxonomy, morphology, and ultrastructure. American Journal of Botany, 77:1544-1557.

Doyle, J.A., Jardiné, S., and Doerenkamp, A. 1982. Afropollis, a new genus of early angiosperm pollen: with notes on the Cretaceous palynostratigraphy and paleoenvironments of Northern Gondwana. Bulletin des Centres de Recherches Exploration-Production Elf-Aquitaine, 6:39-117.

Doyle, J.A., Biens, P., Doerenkamp, A., and Jardiné, S. 1977. Angiosperm pollen from the pre-Albian Cretaceous of Equatorial Africa. Bulletin des Centres de Recherches Exploration-Production Elf-Aquitaine, 1:451-473.

Doyle, J.A., Sauquet, H., Scharaschkin, T., and Le Thomas, A. 2004. Phylogeny, molecular and fossil dating, and biogeographic history of Annonaceae and Myristicaceae (Magnoliales). International Journal of Plant Sciences, 165, supplement:S55-S67.

Drinnan, A.N., Crane, P.R., Friis, E.M., and Pedersen, K.R. 1990. Lauraceous flowers from the Potomac Group (mid-Cretaceous) of eastern North America. Botanical Gazette, 151:370-384.

Eklund, H. 2003. First Cretaceous flowers from Antarctica. Review of Palaeobotany and Palynology, 127:187-217.

Endress, P.K. and Doyle, J.A. 2009. Reconstructing the ancestral angiosperm flower and its initial specializations. American Journal of Botany, 96:22-66.

Erbar, C. and Leins, P. 1981. Zur Spirale in MagnolienBlüten. Beiträge zur Biologie der Pflanzen, 56:225241.

Erkens, R.H.J., Maas, J.W., and Couvreur, T.L.P. 2009. From Africa via Europe to South America: migrational route of a species-rich genus of neotropical lowland rain forest trees (Guatteria, Annonaceae). Journal of Biogeography, 36:2338-2352.

Farley, M.B. and Dilcher, D.L. 1986. Correlation between miospores and depositional environments of the Dakota Formation (mid-Cretaceous) of north-central Kansas and adjacent Nebraska, U.S.A. Palynology, 10:117-133.

Fiet, N., Quidelleur, X., Pariz, O., Bulot, L.G., and Gillot, P.Y. 2006. Lower Cretaceous stage durations combining radiometric data and orbital chronology: Towards a more stable relative time scale? Earth and Planetary Science Letters, 246:407-417.

Forest, F. and Chase, M.W. 2009. Magnoliids, p. 166168. In Hedges, S.B. and Kumar, S. (eds.), The Time Tree of Life. Oxford University Press, New York.

Friis, E.M. 1985. Angiosperm fruits and seeds from the Middle Miocene of Jutland (Denmark). Biologiske Skrifter, Kongelige Danske Videnskabernes Selskab, 24:3-165.
Friis, E.M. and Pedersen, K.R. 2011. Canrightia resinifera gen. et sp. nov., a new extinct angiosperm with Retimonocolpites-type pollen from the Early Cretaceous of Portugal: missing link in the eumagnoliid tree? Grana, 50:3-29.

Friis, E.M., Crane, P.R., and Pedersen, K.R. 2011. Early Flowers and Angiosperm Evolution. Cambridge University Press, New York.

Friis, E.M., Pedersen, K.R., and Crane, P.R. 1995. Appomattoxia ancistrophora gen. et sp. nov., a new Early Cretaceous plant with similarities to Circaeaster and extant Magnoliidae. American Journal of Botany, 82:933-943.

Friis, E.M., Pedersen, K.R., and Crane, P.R. 2010. Cretaceous diversification of angiosperms in the western part of the Iberian Peninsula. Review of Palaeobotany and Palynology, 162:341-361.

Friis, E.M., Eklund, H., Pedersen, K.R., and Crane, P.R. 1994. Virginianthus calycanthoides gen. et sp. nov.A calycanthaceous flower from the Potomac Group (Early Cretaceous) of eastern North America. International Journal of Plant Sciences, 155:772-785.

Frumin, S.I. and Friis, E.M. 1996. Liriodendroid seeds from the Late Cretaceous of Kazakhstan and North Carolina, USA. Review of Palaeobotany and Palynology, 94:39-55.

Frumin, S.I., Eklund, H., and Friis, E.M. 2004. Mauldinia hirsuta sp. nov., a new member of the extinct genus Mauldinia (Lauraceae) from the Late Cretaceous (Cenomanian-Turonian) of Kazakhstan. International Journal of Plant Sciences, 165:883-895.

Gandolfo, M.A., Nixon, K.C., and Crepet, W.L. 2008. Selection of fossils for calibration of molecular dating models. Annals of the Missouri Botanical Garden, 95:34-42.

Góczán, F., Groot, J.J., Krutzsch, W., and Pacltová, B. 1967. Die Gattungen des "Stemma Normapolles Pflug 1953b" (Angiospermae). Paläontologische Abhandlungen Abteilung B, 2:429-539.

González, F., Wagner, S.T., Salomo, K., Symmank, L., Samain, M.-S., Isnard, S., Rowe, N.P., Neinhuis, C., and Wanke, S. 2014. Present trans-Pacific disjunct distribution of Aristolochia subgenus Isotrema (Aristolochiaceae) was shaped by dispersal, vicariance and extinction. Journal of Biogeography, 41:380391.

Gradstein, F.M. 2012. The Geologic Time Scale 2012. Elsevier, Amsterdam.

Graham, S.W. and Olmstead, R.G. 2000. Utility of 17 chloroplast genes for inferring the phylogeny of the basal angiosperms. American Journal of Botany, 87:1712-1730.

Gröcke, D.R., Ludvigson, G.A., Witzke, B.L., Robinson, S.A., Joeckel, R.M., Ufnar, D.F., and Ravn, R.L. 2006. Recognizing the Albian-Cenomanian (OAE1d) sequence boundary using plant carbon isotopes: Dakota Formation, Western Interior Basin, USA. Geology, 34:193-196. 
Groot, J.J., Penny, J.S., and Groot, C.R. 1961. Plant microfossils and age of the Raritan, Tuscaloosa and Magothy formations of the eastern United States. Palaeontographica Abteilung B, 108:121-140.

Gübeli, A.A., Hochuli, P.A., and Wildi, W. 1984. Lower Cretaceous turbiditic sediments from the Rif chain (Northern Marocco) - palynology, stratigraphy and palaeogeographic setting. Geologische Rundschau, 73:1081-1114.

Hedlund, R.W. and Norris, G. 1968. Spores and pollen grains from Fredericksburgian (Albian) strata, Marshall County, Oklahoma. Pollen et Spores, 10:129_ 159.

Heimhofer, U. and Hochuli, P.A. 2010. Early Cretaceous angiosperm pollen from a low-latitude succession (Araripe Basin, NE Brazil). Review of Palaeobotany and Palynology, 161:105-126.

Heimhofer, U., Hochuli, P.A., Burla, S., and Weissert, H. 2007. New records of Early Cretaceous angiosperm pollen from Portuguese coastal deposits: Implications for the timing of the early angiosperm radiation. Review of Palaeobotany and Palynology, 144:39-76.

Heimhofer, U., Hochuli, P.A., Burla, S., Dinis, J.M.L., and Weissert, H. 2005. Timing of Early Cretaceous angiosperm diversification and possible links to major paleoenvironmental change. Geology, 33:141-144.

Helby, R.J., Morgan, R., and Partridge, A.D. 1987. A palynological zonation of the Australian Mesozoic. Memoirs of the Association of Australasian Palaeontologists, 4:1-94.

Herendeen, P.S. 1991. Lauraceous wood from the midCretaceous Potomac group of eastern North America: Paraphyllanthoxylon marylandense sp. nov. Review of Palaeobotany and Palynology, 69:277290.

Hills, L.V. and Baadsgaard, H. 1967. Potassium-argon dating of some Lower Tertiary strata in British Columbia. Bulletin of Canadian Petroleum Geology, 15:138-149.

Hilu, K.W., Borsch, T., Müller, K., Soltis, D.E., Soltis, P.S., Savolainen, V., Chase, M.W., Powell, M.P., Anderberg, A.A., Evans, R., Sauquet, H., Neinhuis, C., Slotta, T.A.B., Rohwer, J.G., Campbell, C.S., and Chatrou, L.W. 2003. Angiosperm phylogeny based on matK sequence information. American Journal of Botany, 90:1758-1776.

Hochuli, P.A., Heimhofer, U., and Weissert, H. 2006. Timing of early angiosperm radiation: recalibrating the classical succession. Journal of the Geological Society, 163:587-594.

Huang, C., Hinnov, L., Fischer, A.G., Grippo, A., and Herbert, T. 2010. Astronomical tuning of the Aptian Stage from Italian reference sections. Geology, 38:899902.

Hughes, N.F. 1994. The Enigma of Angiosperm Origins. Cambridge University Press, Cambridge, UK.
Igersheim, A. and Endress, P.K. 1997. Gynoecium diversity and systematics of the Magnoliales and winteroids. Botanical Journal of the Linnean Society, 124:213-271.

Inoue, J.G., Donoghue, P.C.J., and Yang, Z. 2010. The impact of the representation of fossil calibrations on Bayesian estimation of species divergence times. Systematic Biology, 59:74-89.

Jansen, R.K., Cai, Z., Raubeson, L.A., Daniell, H., Depamphilis, C.W., Leebens-Mack, J., Müller, K.F., Guisinger-Bellian, M., Haberle, R.C., Hansen, A.K., Chumley, T.W., Lee, S.-B., Peery, R., McNeal, J.R., Kuehl, J.V, and Boore, J.L. 2007. Analysis of 81 genes from 64 plastid genomes resolves relationships in angiosperms and identifies genome-scale evolutionary patterns. Proceedings of the National Academy of Sciences of the United States of America, 104:19369-19374.

Jaramillo, M.A., Manos, P.S., and Zimmer, E.A. 2004. Phylogenetic relationships of the perianthless Piperales: reconstructing the evolution of floral development. International Journal of Plant Sciences, 165:403-416.

Kelly, L.M. and González, F. 2003. Phylogenetic relationships in Aristolochiaceae. Systematic Botany, 28:236-249.

Kemp, E.M. 1970. Aptian and Albian miospores from southern England. Palaeontographica Abteilung B, 131:73-143.

Kluge, A.G. 1989. A concern for evidence and a phylogenetic hypothesis for relationships among Epicrates (Boidae, Serpentes). Systematic Zoology, 38:1-25.

Knobloch, E. and Mai, D.H. 1986. Monographie der Frütchte und Samen in der Kreide von Mitteleuropa. Rozpravy Ústředního Ústavu Geologického, Praha, 47:1-219.

Kulkarni, A.R. and Patil, K.S. 1977. Aristolochioxylon prakashii from the Deccan Intertrappean beds of Wardha District, Maharashtra. Geophytology, 7:4449.

Kvaček, Z. 1992. Lauralean angiosperms in the Cretaceous. Courier Forschungsinstitut Senckenberg, 147:345-367.

Kvaček, J. and Eklund, H. 2003. A report on newly recovered reproductive structures from the Cenomanian of Bohemia (Central Europe). International Journal of Plant Sciences, 164:1021-1039.

Laing, J.F. 1975. Mid-Cretaceous angiosperm pollen from southern England and northern France. Palaeontology, 18:775-808.

Ludvigson, G.A., Witzke, B.J., Joeckel, R.M., Ravn, R.L., Phillips, P.L., González, L.A., and Brenner, R.L. 2010. New insights on the sequence stratigraphic architecture of the Dakota Formation in KansasNebraska-lowa from a decade of sponsored research activity. Current Research in Earth Sciences Bulletin, 258:1-35. 
MacGinitie, H.D. 1974. An early middle Eocene flora from the Yellowstone-Absaroka Volcanic province, northwestern Wind River Basin, Wyoming. University of California Publications in Geological Sciences, 108:1-103.

Macphail, M.K., Alley, N.F., Truswell, E.M., and Sluiter, I.R.K. 1994. Early Tertiary vegetation: evidence from spores and pollen, p. 189-261. In Hill, R.S. (ed.), History of the Australian Vegetation: Cretaceous to Recent. Cambridge University Press, Cambridge, UK.

Magallón, S. 2010. Using fossils to break long branches in molecular dating: a comparison of relaxed clocks applied to the origin of angiosperms. Systematic Biology, 59:384-399.

Magallón, S. and Castillo, A. 2009. Angiosperm diversification through time. American Journal of Botany, 96:349-65.

Magallón, S.A. and Sanderson, M.J. 2005. Angiosperm divergence times: the effect of genes, codon positions, and time constraints. Evolution, 59:1653-1670.

Magallón, S.A., Hilu, K.W., and Quandt, D. 2013. Land plant evolutionary timeline: gene effects are secondary to fossil constraints in relaxed clock estimation of age and substitution rates. American Journal of Botany, 100:556-573.

Mancini, E.A. and Puckett, T.M. 2005. Jurassic and Cretaceous transgressive-regressive (T-R) cycles, northern Gulf of Mexico, USA. Stratigraphy, 2:31-48.

Marquínez, X., Lohmann, L.G., Salatino, M.L.F., Salatino, A., and González, F. 2009. Generic relationships and dating of lineages in Winteraceae based on nuclear (ITS) and plastid (rpS16 and psbA-trnH) sequence data. Molecular Phylogenetics and Evolution, 53:435-449.

Massoni, J., Forest, F., and Sauquet, H. 2014. Increased sampling of both genes and taxa improves resolution of phylogenetic relationships within Magnoliidae, a large and early-diverging clade of angiosperms. Molecular Phylogenetics and Evolution, 70:84-93.

Mathews, W.H. 1964. Potassium-argon age determinations of Cenozoic volcanic rocks from British Columbia. Geological Society of America Bulletin, 75:465468.

Mathews, S. and Donoghue, M.J. 1999. The root of angiosperm phylogeny inferred from duplicate phytochrome genes. Science, 286:947-950.

Mathews, S. and Donoghue, M.J. 2000. Basal angiosperm phylogeny inferred from duplicate phytochromes A and C. International Journal of Plant Sciences, 161, supplement:S41-S55.

Meng, S.-W., Chen, Z.-D., Li, D.-Z., and Liang, H.-X. 2002. Phylogeny of Saururaceae based on mitochondrial matR gene sequence data. Journal of Plant Research, 115:71-76.
Meng, S.-W., Douglas, A.W., Li, D.-Z., Chen, Z.-D., Liang, H.-X., and Yang, J.-B. 2003. Phylogeny of Saururaceae based on morphology and five regions from three plant genomes. Annals of the Missouri Botanical Garden, 90:592-602.

Meredith, R.W., Janečka, J.E., Gatesy, J., Ryder, O.A., Fisher, C.A., Teeling, E.C., Goodbla, A., Eizirik, E., Simão, T.L.L., Stadler, T., Rabosky, D.L., Honeycutt, R.L., Flynn, J.J., Ingram, C.M., Steiner, C., Williams, T.L., Robinson, T.J., Burk-Herrick, A., Westerman, M., Ayoub, N.A., Springer, M.S., and Murphy, W.J. 2011. Impacts of the Cretaceous Terrestrial Revolution and $\mathrm{KPg}$ extinction on mammal diversification. Science, 334:521-524.

Michalak, I., Zhang, L.-B., and Renner, S.S. 2010. TransAtlantic, trans-Pacific and trans-Indian Ocean dispersal in the small Gondwanan Laurales family Hernandiaceae. Journal of Biogeography, 37:1214-1226.

Mohr, B.A.R. and Bernardes-de-Oliveira, M.E.C. 2004. Endressinia brasiliana, a magnolialean angiosperm from the Lower Cretaceous Crato Formation (Brazil). International Journal of Plant Sciences, 165:11211133.

Mohr, B.A.R. and Eklund, H. 2003. Araripia florifera, a magnoliid angiosperm from the Lower Cretaceous Crato Formation (Brazil). Review of Palaeobotany and Palynology, 126:279-292.

Mohr, B.A.R., Coiffard, C., and Bernardes-de-Oliveira, M.E.C. 2013. Schenkeriphyllum glanduliferum, a new magnolialean angiosperm from the Early Cretaceous of Northern Gondwana and its relationships to fossil and modern Magnoliales. Review of Palaeobotany and Palynology, 189:57-72.

Moore, M.J., Bell, C.D., Soltis, P.S., and Soltis, D.E. 2007. Using plastid genome-scale data to resolve enigmatic relationships among basal angiosperms. Proceedings of the National Academy of Sciences of the United States of America, 104:19363-8.

Moore, M.J., Soltis, P.S., Bell, C.D., Burleigh, J.G., and Soltis, D.E. 2010. Phylogenetic analysis of 83 plastid genes further resolves the early diversification of eudicots. Proceedings of the National Academy of Sciences of the United States of America, 107:46234628.

Moss, P.T., Greenwood, D.R., and Archibald, S.B. 2005. Regional and local vegetation community dynamics of the Eocene Okanagan Highlands (British Columbia - Washington State) from palynology. Canadian Journal of Earth Sciences, 42:187-204.

Mustoe, G.E. 2011. Cyclic sedimentation in the Eocene Allenby Formation of south-central British Columbia and the origin of the Princeton Chert fossil beds. Canadian Journal of Earth Sciences, 48:25-43.

Neinhuis, C., Wanke, S., Hilu, K.W., Müller, K., and Borsch, T. 2005. Phylogeny of Aristolochiaceae based on parsimony, likelihood, and Bayesian analyses of trnL-trnF sequences. Plant Systematics and Evolution, 250:7-26. 
Nickrent, D.L., Blarer, A., Qiu, Y.-L., Soltis, D.E., Soltis, P.S., and Zanis, M.J. 2002. Molecular data place Hydnoraceae with Aristolochiaceae. American Journal of Botany, 89:1809-1817.

Ogg, J.G. and Hinnov, L.A. 2012. Cretaceous, p. 793853. In Gradstein, F.M. (ed.), The Geologic Time Scale 2012. Elsevier, Amsterdam.

Pacltová, B. 1971. Palynological study of Angiospermae from the Peruc Formation (?Albian-Lower Cenomanian) of Bohemia. Ústřední Ústav Geologický, Sborník Geologických Věd, řada P, 13:105-141.

Pacltová, B. 1977. Cretaceous angiosperms of Bohemia - Central Europe. Botanical Review, 43:128-142.

Parham, J.F., Donoghue, P.C.J., Bell, C.J., Calway, T.D., Head, J.J., Holroyd, P.A., Inoue, J.G., Irmis, R.B., Joyce, W.G., Ksepka, D.T., Patané, J.S.L., Smith, N.D., Tarver, J.E., van Tuinen, M., Yang, Z., Angielczyk, K.D., Greenwood, J.M., Hipsley, C.A., Jacobs, L., Makovicky, P.J., Müller, J., Smith, K.T., Theodor, J.M., Warnock, R.C.M., and Benton, M.J. 2012. Best practices for justifying fossil calibrations. Systematic Biology, 61:346-359.

Penny, J.H.J. 1988a. Early Cretaceous striate tricolpate pollen from the Borehole Mersa Matruh 1, North West Desert, Egypt. Journal of Micropalaeontology, 7:201-215.

Penny, J.H.J. 1988b. Early Cretaceous acolumellate semitectate pollen from Egypt. Palaeontology, 31:373-418.

Penny, J.H.J. 1989. New Early Cretaceous forms of the angiosperm pollen genus Afropollis from England and Egypt. Review of Palaeobotany and Palynology, 58:289-299.

Pierce, R.L. 1961. Lower Upper Cretaceous plant microfossils from Minnesota. Minnesota Geological Survey Bulletin, 42:1-86.

Pirie, M.D., Chatrou, L.W., Mols, J.B., Erkens, R.H.J., and Oosterhof, J. 2006. "Andean-centred" genera in the short-branch clade of Annonaceae: testing biogeographical hypotheses using phylogeny reconstruction and molecular dating. Journal of Biogeography, 33:31-46.

Pirie, M.D. and Doyle, J.A. 2012. Dating clades with fossils and molecules: the case of Annonaceae. Botanical Journal of the Linnean Society, 169:84-116.

Plummer, N. and Romary, F.J. 1942. Stratigraphy of the pre-Greenhorn Cretaceous beds of Kansas. Kansas Geological Survey Bulletin, 41:313-348.

Poinar, G. and Chambers, K.L. 2005. Palaeoanthella huangii gen. and sp. nov., an Early Cretaceous flower (Angiospermae) in Burmese amber. Sida, 21:20872092.

Pons, D., Berthou, P.Y., Filgueira, J.B.M., and Sampaio, J.J.A. 1996. Palynologie des unités lithostratigraphiques "Fundão", "Crato" et "Ipubi" (Aptien supérieur à Albien inférieur moyen, Bassin d'Araripe, NE du Brésil): Enseignements paléoécologiques, stra- tigraphiques et climatologiques. Geologie de l'Afrique et de l'Atlantique Sud. Bulletin des Centres de Recherches Exploration-Production Elf-Aquitaine, Mémoire 16:383-401.

Poole, I. and Gottwald, H. 2001. Monimiaceae sensu lato, an element of Gondwanan polar forests: Evidence from the Late Cretaceous-Early Tertiary wood flora of Antarctica. Australian Systematic Botany, 14:207-230.

Pyron, R.A. 2011. Divergence time estimation using fossils as terminal taxa and the origins of Lissamphibia. Systematic Biology, 60:466-481.

Qiu, Y.-L., Li, L., Hendry, T.A., Li, R., Taylor, D.W., Issa, M.J., Ronen, A.J., Vekaria, M.L., and White, A.M. 2006. Reconstructing the basal angiosperm phylogeny: evaluating information content of mitochondrial genes. Taxon, 55:837-856.

Qiu, Y.-L., Lee, J., Bernasconi-Quadroni, F., Soltis, D.E., Soltis, P.S., Zanis, M.J., Zimmer, E.A., Chen, Z., Savolainen, V., and Chase, M.W. 1999. The earliest angiosperms: evidence from mitochondrial, plastid and nuclear genomes. Nature, 402:404-407.

Qiu, Y.-L., Lee, J., Bernasconi-Quadroni, F., Soltis, D.E., Soltis, P.S., Zanis, M.J., Zimmer, E.A., Chen, Z., Savolainen, V., and Chase, M.W. 2000. Phylogeny of basal angiosperms: analyses of five genes from three genomes. International Journal of Plant Sciences, 161, supplement:S3-S27.

Qiu, Y.-L., Li, L., Wang, B., Xue, J.-Y., Hendry, T.A., Li, R.-Q., Brown, J.W., Liu, Y., Hudson, G.T., and Chen, Z.-D. 2010. Angiosperm phylogeny inferred from sequences of four mitochondrial genes. Journal of Systematics and Evolution, 48:391-425.

Qiu, Y.-L., Dombrovska, O., Lee, J., Li, L., Whitlock, B.A., Bernasconi-Quadroni, F., Rest, J.S., Davis, C.C., Borsch, T., Hilu, K.W., Renner, S.S., Soltis, D.E., Soltis, P.S., Zanis, M.J., Cannone, J.J., Gutell, R.R., Powell, M., Savolainen, V., Chatrou, L.W., and Chase, M.W. 2005. Phylogenetic analyses of basal angiosperms based on nine plastid, mitochondrial, and nuclear genes. International Journal of Plant Sciences, 166:815-842.

Read, P.B. 2000. Geology and industrial minerals of the Tertiary basins, south-central British Columbia. British Columbia Geological Survey Geo-File, 20002003.

Regali, M.S.P. and Viana, C.F. 1989. Late Jurassic-Early Cretaceous in Brazilian Sedimentary Basins: Correlation with the International Standard Scale. Petrobras, Rio de Janeiro.

Renner, S.S. 1998. Phylogenetic affinities of Monimiaceae based on cpDNA gene and spacer sequences. Perspectives in Plant Ecology, Evolution and Systematics, 1:61-77.

Renner, S.S. 1999. Circumscription and phylogeny of the Laurales: evidence from molecular and morphological data. American Journal of Botany, 86:1301-1315. 
Renner, S.S. 2004. Variation in diversity among Laurales, Early Cretaceous to present. Biologiske Skrifter Det Kongelige Danske Videnskabernes Selskab, 55:441-458.

Renner, S.S. and Chanderbali, A.S. 2000. What is the relationship among Hernandiaceae, Lauraceae, and Monimiaceae, and why is this question so difficult to answer? International Journal of Plant Sciences, 161, supplement:S109-S119.

Renner, S.S., Strijk, J.S., Strasberg, D., and Thébaud, C. 2010. Biogeography of the Monimiaceae (Laurales): a role for East Gondwana and long-distance dispersal, but not West Gondwana. Journal of Biogeography, 37:1227-1238.

Retallack, G.J. and Dilcher, D.L. 1981. Early angiosperm reproduction: Prisca reynoldsii, gen. et sp. nov. from mid-Cretaceous coastal deposits in Kansas, U.S.A. Palaeontographica Abteilung B, 179:103-137.

Retallack, G.J. and Dilcher, D.L. 2012. Outcrop versus core and geophysical log interpretation of mid-Cretaceous paleosols from the Dakota Formation of Kansas. Palaeogeography, Palaeoclimatology, Palaeoecology, 329-330:47-63.

Richardson, J.E., Chatrou, L.W., Mols, J.B., Erkens, R.H.J., and Pirie, M.D. 2004. Historical biogeography of two cosmopolitan families of flowering plants: Annonaceae and Rhamnaceae. Philosophical Transactions of the Royal Society of London. Series B, Biological Sciences, 359:1495-508.

Rohwer, J.G. and Rudolph, B. 2005. Jumping genera: the phylogenetic positions of Cassytha, Hypodaphnis, and Neocinnamomum (Lauraceae) based on different analyses of trnK intron sequences. Annals of the Missouri Botanical Garden, 92:153-178.

Romanov, M.S. and Dilcher, D.L. 2013. Fruit structure in Magnoliaceae s.l. and Archaeanthus and their relationships. American Journal of Botany, 100:14941508.

Ronquist, F., Klopfstein, S., Vilhelmsen, L., Schulmeister, S., Murray, D.L., and Rasnitsyn, A.P. 2012. A totalevidence approach to dating with fossils, applied to the early radiation of the Hymenoptera. Systematic Biology, 61:973-999.

Rouse, G.E. and Mathews, W.H. 1961. Radioactive dating of Tertiary plant-bearing deposits. Science, 133:1079-1080.

Rüffle, L. and Knappe, H. 1988. Ökologische und paläogeographische Bedeutung der Oberkreideflora von Quedlinburg, besonders einiger Loranthaceae und Monimiaceae. Hallesche Jahrbücher für Geowissenschaften, 13:49-65.

Russell, L.S. 1935. A Middle Eocene mammal from British Columbia. American Journal of Science, 29:5455.

Sanderson, M.J. 1997. A nonparametric approach to estimating divergence times in the absence of rate constancy. Molecular Biology and Evolution, 14:1218-1231.
Sauquet, H., Doyle, J.A., Scharaschkin, T., Borsch, T., Hilu, K.W., Chatrou, L.W., and Le Thomas, A. 2003. Phylogenetic analysis of Magnoliales and Myristicaceae based on multiple data sets: implications for character evolution. Botanical Journal of the Linnean Society, 142:125-186.

Sauquet, H., Ho, S.Y.W., Gandolfo, M.A., Jordan, G.J., Wilf, P., Cantrill, D.J., Bayly, M.J., Bromham, L., Brown, G.K., Carpenter, R.J., Lee, D.M., Murphy, D.J., Sniderman, J.M.K., and Udovicic, F. 2012. Testing the impact of calibration on molecular divergence times using a fossil-rich group: the case of Nothofagus (Fagales). Systematic Biology, 61:289-313.

Savolainen, V., Chase, M.W., Hoot, S.B., Morton, C.M., Soltis, D.E., Bayer, C., Fay, M.F., de Bruijn, A.Y., Sullivan, S., Qiu, Y.-L. 2000. Phylogenetics of flowering plants based on combined analysis of plastid atpB and $r b c L$ gene sequences. Systematic Biology, 49:306-362.

Schöning, M. and Bandel, K. 2004. A diverse assemblage of fossil hardwood from the Upper Tertiary (Miocene?) of the Arauco Peninsula, Chile. Journal of South American Earth Sciences, 17:59-71.

Schrank, E. 2013. New taxa of winteraceous pollen from the Lower Cretaceous of Israel. Review of Palaeobotany and Palynology, 195:19-25.

Scott R.W., Oboh-lkuenobe F.E., Benson D.G., and Holbrook J.M. 2009. Numerical age calibration of the Albian/Cenomanian boundary. Stratigraphy, 6:17-32.

Sirkin, L.A. 1974. Palynology and stratigraphy of Cretaceous strata in Long Island, New York, and Block Island, Rhode Island. U.S. Geological Survey Journal of Research, 2:431-440.

Smith, S.Y. and Stockey, R.A. 2007. Establishing a fossil record for the perianthless Piperales: Saururus tuckerae sp. nov. (Saururaceae) from the Middle Eocene Princeton Chert. American Journal of Botany, 94:1642-1657.

Smith, S.A., Beaulieu, J.M., and Donoghue, M.J. 2010. An uncorrelated relaxed-clock analysis suggests an earlier origin for flowering plants. Proceedings of the National Academy of Sciences of the United States of America, 107:5897-5902.

Smith, J.F., Stevens, A.C., Tepe, E.J., and Davidson, C. 2008. Placing the origin of two species-rich genera in the Late Cretaceous with later species divergence in the Tertiary: a phylogenetic, biogeographic and molecular dating analysis of Piper and Peperomia (Piperaceae). Plant Systematics and Evolution, 275:9-30.

Soltis, D.E., Gitzendanner, M.A., and Soltis, P.S. 2007. A 567-taxon data set for angiosperms: the challenges posed by Bayesian analyses of large data sets. International Journal of Plant Sciences, 168:137-157.

Soltis, P.S., Soltis, D.E., and Chase, M.W. 1999. Angiosperm phylogeny inferred from multiple genes as a tool for comparative biology. Nature, 402:402-404. 
Soltis, P.S., Soltis, D.E., and Zanis, M.J. 2000b. Basal lineages of angiosperms: relationships and implications for floral evolution. International Journal of Plant Sciences, 161, supplement:S97-S107.

Soltis, D.E., Bell, C.D., Kim, S., and Soltis, P.S. 2008. Origin and early evolution of angiosperms. Annals of the New York Academy of Sciences, 1133:3-25.

Soltis, D.E., Soltis, P.S., Chase, M.W., Mort, M.E., Aalbach, D.C., Zanis, M.J., Savolainen, V., Hahn, W.H., Hoot, S.B., Fay, M.F., Axtell, M., Swensen, S.M., Prince, L.M., Kress, W.J., Nixon, K.C., and Farris, J.S. 2000a. Angiosperm phylogeny inferred from $18 \mathrm{~S}$ rDNA, rbcL, and atpB sequences. Botanical Journal of the Linnean Society, 133:381-461.

Soltis, D.E., Smith, S.A., Cellinese, N., Wurdack, K.J., Tank, D.C., Brockington, S.F., Refulio-Rodriguez, N.F., Walker, J.B., Moore, M.J., Carlsward, B.S., Bell, C.D., Latvis, M., Crawley, S., Black, C., Diouf, D., Xi, Z., Rushworth, C.A., Gitzendanner, M.A., Sytsma, K.J., Qiu, Y.-L., Hilu, K.W., Davis, C.C., Sanderson, M.J., Beaman, R.S., Olmstead, R.G., Judd, W.S., Donoghue, M.J., and Soltis, P.S. 2011. Angiosperm phylogeny: 17 genes, 640 taxa. American Journal of Botany, 98:704-730.

Springer, M.S., Teeling, E.C., Madsen, O., Stanhope, M.J., and de Jong, W.W. 2001. Integrated fossil and molecular data reconstruct bat echolocation. Proceedings of the National Academy of Sciences of the United States of America, 98:6241-6246.

Stopes, M.C. and Fujii, K. 1911. Studies on the structure and affinities of Cretaceous plants. Philosophical Transactions of the Royal Society of London, 201:190.

Su, Y.C.F. and Saunders, R.M.K. 2009. Evolutionary divergence times in the Annonaceae: evidence of a late Miocene origin of Pseuduvaria in Sundaland with subsequent diversification in New Guinea. BMC Evolutionary Biology, 9:153.

Surveswaran, S., Wang, R.J., Su, Y.C.F., and Saunders, R.M.K. 2010. Generic delimitation and historical biogeography in the early-divergent "ambavioid" lineage of Annonaceae: Cananga, Cyathocalyx and Drepananthus. Taxon, 59:1721-1734.

Takahashi, M., Herendeen, P.S., and Crane, P.R. 2001. Lauraceous fossil flower from the Kamikitaba Locality (Lower Coniacian; Upper Cretaceous) in northeastern Japan. Journal of Plant Research, 114:429-434.

Takahashi, M., Friis, E.M., Uesugi, K., Suzuki, Y., and Crane, P.R. 2008. Floral evidence of Annonaceae from the Late Cretaceous of Japan. International Journal of Plant Sciences, 169:908-917.

Tucker, S.C. and Douglas, A.W. 1996. Floral structure, development and relationships of paleoherbs: Saruma, Cabomba, Lactoris and selected Piperales, p. 141-175. In Taylor, D.W. and Hickey, L.J. (eds.), Flowering Plant Origin, Evolution and Phylogeny. Chapman \& Hall, New York.
Tucker, S.C., Douglas, A.W., and Liang, H,.-X., L. 1993. Utility of ontogenetic and conventional characters in determining phylogenetic relationships of Saururaceae and Piperaceae (Piperales). Systematic Botany, 18:614-641.

Uličný, D., Kvaček, J., Svobodová, M., and Špičáková, L. 1997. High-frequency sea-level fluctuations and plant habitats in Cenomanian fluvial to estuarine succession: Pecínov quarry, Bohemia. Palaeogeography, Palaeoclimatology, Palaeoecology, 136:165-197.

Upchurch, G.R. and Dilcher, D.L. 1990. Cenomanian angiosperm leaf megafossils, Dakota Formation, Rose Creek locality, Jefferson County, southeastern Nebraska. U.S. Geological Survey Bulletin, 1915:155.

van Setten, A.K. and Koek-Noorman, J. 1992. Fruits and seeds of Annonaceae. Morphology and its significance for classification and identification. Studies in Annonaceae XVII. Bibliotheca Botanica, Stuttgart, 142:1-101.

Viehofen, A., Hartkopf-Fröder, C., and Friis, E.M. 2008. Inflorescences and flowers of Mauldinia angustiloba sp. nov. (Lauraceae) from Middle Cretaceous karst infillings in the Rhenish Massif, Germany. International Journal of Plant Sciences, 169:871-889.

von Balthazar, M., Crane, P.R., Pedersen, K.R., and Friis, E.M. 2011. New flowers of Laurales from the Early Cretaceous (Early to Middle Albian) of eastern North America, p. 49-87. In Wanntorp, L. and Ronse De Craene, L.P. (eds.), Flowers on the Tree of Life. Cambridge University Press, Cambridge, UK.

Walker, J.W., Brenner, G.J., and Walker, A.G. 1983. Winteraceous pollen in the Lower Cretaceous of Israel: Early evidence of a magnolialean angiosperm family. Science, 220:1273-1275.

Wanke, S., Jaramillo, M.A., Borsch, T., Samain, M.-S., Quandt, D., and Neinhuis, C. 2007a. Evolution of Piperales--matK gene and trnK intron sequence data reveal lineage specific resolution contrast. Molecular Phylogenetics and Evolution, 42:477-497.

Wanke, S., Vanderschaeve, L., Mathieu, G., Neinhuis, C., Goetghebeur, P., and Samain, M.S. 2007b. From forgotten taxon to a missing link? The position of the genus Verhuellia (Piperaceae) revealed by molecules. Annals of Botany, 99:1231-1238.

Ward, J.V. 1986. Early Cretaceous angiosperm pollen from the Cheyenne and Kiowa Formations (Albian) of Kansas, U.S.A. Palaeontographica Abteilung B, 202:1-81.

Wikström, N., Savolainen, V., and Chase, M.W. 2001. Evolution of the angiosperms: calibrating the family tree. Proceedings of the Royal Society, Biological Sciences, 268:2211-2220.

Wilson, M.V.H. 1982. A new species of the fish Amia from the Middle Eocene of British Columbia. Paleontology, 25:413-424. 
Wolfe, J.A. and Pakiser, H.M. 1971. Stratigraphic interpretations of some Cretaceous microfossil floras of the middle Atlantic states. U.S. Geological Survey Professional Paper, 750-B:B35-B47.

Zanis, M.J., Soltis, D.E., Soltis, P.S., Mathews, S., and Donoghue, M.J. 2002. The root of the angiosperms revisited. Proceedings of the National Academy of Sciences of the United States of America, 99:68486853.
Zanis, M.J., Soltis, P.S., Qiu, Y.-L., Zimmer, E., and Soltis, D.E. 2003. Phylogenetic analyses and perianth evolution in basal angiosperms. Annals of the Missouri Botanical Garden, 90:129-150.

Zavada, M.S. and Benson, J.M. 1987. First fossil evidence for the primitive angiosperm family Lactoridaceae. American Journal of Botany, 74:1590-1594.

Zhou, S., Renner, S.S., and Wen, J. 2006. Molecular phylogeny and intra- and intercontinental biogeography of Calycanthaceae. Molecular Phylogenetics and Evolution, 39:1-15. 